Check for updates

Cite this: RSC Adv., 2020, 10, 5487

Received 3rd November 2019

Accepted 20th December 2019

DOI: $10.1039 / c 9 r a 09084 c$

rsc.li/rsc-advances

\section{$\alpha$-Santalol functionalized chitosan nanoparticles as efficient inhibitors of polo-like kinase in triple negative breast cancer}

\author{
Jinku Zhang, $\mathbb{D} \dagger^{\star \mathrm{a}}$ Yanan Wang, $\dagger^{\mathrm{b}} \mathrm{Jinmei}^{\mathrm{Li}}{ }^{\mathrm{a}}$ Wenming Zhao, ${ }^{\mathrm{a}}$ Zhao Yang ${ }^{\mathrm{c}}$ \\ and Yanguang Feng*d
}

Polo-like kinase 1 (PLK-1) is a protein kinase that plays a significant role in the initiation, maintenance, and completion of mitotic processes in the cell cycle. PLK-1 has been recorded to be over-expressed in various human cancers and is associated with poor prediction; thus it is an attractive target for anticancer therapy. Novel $\alpha$-santalol functionalized chitosan nanoparticles were synthesized using the sol gel method and were assessed for their in vitro (MTT, apoptotic staining assays, and cell cycle analysis) and in vivo activities. $\alpha$ Santalol loaded chitosan NPs inhibited the proliferation of triple negative breast cancer (MDA-MB-231) at an inhibitory concentration of $\left(\mathrm{IC}_{50}\right)$ about $4.5 \mu \mathrm{g} \mathrm{mL}$; meanwhile, in normal cells, no adverse effects were exhibited up to $100 \mu \mathrm{g} \mathrm{mL} \mathrm{m}^{-1}$. The findings also implicated a decreased expression of the antiapoptotic protein, BCL-2 with PLK-1 and an increase in the expression of BAD, caspases and BAX. However, in in vivo studies, the treated animal group exhibited no aberrant effects in vital organs or blood parameters. Tumor growth was significantly inhibited after i.v. injection of $\alpha$-santalol loaded chitosan NPs at a dose of $5 \mathrm{mg} \mathrm{kg}^{-1}$. Taken together, the $\alpha$-santalol functionalized chitosan NPs hold great potential in biomedical applications, especially cancer theranostics, due to their versatile nature as well as diagnostics for clinical tumor biology.

\section{Introduction}

Triple negative breast cancer (TNBC), a heterogeneous and aggressive cancer with a poor prognosis, comprises $15-20 \%$ of the overall breast cancer cases worldwide. The percentage of TNBC cases ranges from $6.7-27.9 \%$ in different countries and India has the highest rate amongst all of them with $27.9 \%$, followed by Indonesia, Algeria, and Pakistan. ${ }^{1}$ The triple negative breast cancer cells lack of expression of estrogen (ER), progesterone (PR) and human epidermal growth factor 2 (HER 2) receptors on cell surface. ${ }^{2}$ TNBC has a propensity to propagate to various visceral organs including the liver and lung. ${ }^{3}$ Due to the absence of the receptors, the cancer cells do not react to either endocrine or HER-2 targeted therapies. Thus, the recent research findings by various researchers in treating TNBC relies

\footnotetext{
${ }^{a}$ Department of Pathology, Baoding First Central Hospital, Baoding, 071000, Hebei province, China.E-mail: zjkblk@sina.com

${ }^{b}$ Department of Pathology, Affiliated Hospital of Hebei University, Baoding, 071000, Hebei province, China

${ }^{c}$ College of Life Science and Technology, Beijing University of Chemical Technology, Beijing, 010000, China

${ }^{d}$ Department of Cardiology, Baoding Qingyuan District People's Hospital, Baoding, 071100, Hebei province, China. E-mail: 13930832196fyg@sina.com

$\dagger$ Equally contributed to the work.
}

on targeting it with PARP inhibitors, including the PD-L1 protein. ${ }^{4}$

One example involves the inhibition of polo-like kinase 1 (PLK-1), which pertains to the polo-like kinase family and is referred to as the master mitotic regulator. ${ }^{5}$ The PLK- 1 gene is characterized by the presence of the canonical kinase catalytic domain with a regulatory domain of one or two polo-box domains (PBD). ${ }^{6}$ It is a pivotal gene responsible for the proper accomplishment of the cell division. ${ }^{7}$ PLK-1 is the responsible candidate gene and is highly synchronized with multi-layered regulation as it plays a pivotal role in the manifold stages of cell division including the entry of the cell into mitotic division, ${ }^{8}$ centrosome disjunction and movement, spindle formation, ${ }^{9}$ activation of anaphase by forming complexes, ${ }^{10}$ and cytokinesis. ${ }^{11}$ PLK-1 gene function is not only narrowed down to cell division but it is also responsible for DNA replication, transcription, translation, p53 regulation, and cell motility. ${ }^{12-16}$ PLK1 expression is reported to be increased in various cancers including colon cancer, breast cancer, gastric cancer, and osteosarcoma and is embodied as an oncogene. ${ }^{17,18}$ For this reason, PLK-1 has served as a marker for various kinds of prognostic cancers ${ }^{19}$ and also has been used as a therapeutic target in various cancer studies. ${ }^{20,21}$

Thus, as a respite for TNBC, the PLK-1 gene was targeted with chitosan NPs. The NPs are nano-sized colloidal particles with a diameter of $10-500 \mathrm{~nm}$, through which the bioactive 
compound can be loaded, adsorbed or conjugated. ${ }^{22}$ Chitosan (poly[-(1,4)-2-amino-2-deoxy-D-glucopyranose]), a naturally abundant bioactive polymer, formed by the deacetylation of chitin, is known for its myriad of properties including biodegradability, non-immunogenicity, biocompatibility, and nontoxicity. ${ }^{23}$ It is an FDA approved co-polymer consisting of glucosamine and $N$-acetyl glucosamine, which are cross-linked by a 1,4-glycosidic bond. Moreover, chitosan has the propensity to encapsulate or coat a drug over the surface and can also control the drug release proficiency. ${ }^{24}$ The polymer has been investigated as an adjuvant and for a wide variety of activities, including anti-microbial activity, anti-tumor activity, blood hemostatic activity, and anti-diabetic activity, as well as for enzyme immobilization and wound dressing applications. ${ }^{25-28}$ The mucoadhesive nature of chitosan raises the residual time at the site of absorption and its cationic property permits ionic linkages, which happens with multivalent anions. ${ }^{29}$

Different methods have been employed for synthesizing the chitosan NPs including ionic gelation using cross-linking agents (tripolyphosphate (TPP) ${ }^{30}$ or glutaraldehyde), ${ }^{31}$ the emulsion solvent evaporation method, ${ }^{32}$ and coacervation phase separation. ${ }^{33}$ In the present study, the chitosan NPs were synthesized using the ionic gelation method, where the NPs are formed by the interaction between positively charged chitosan chains $\left(-\mathrm{NH}_{3}{ }^{+}\right)$and the polyanion, which are used as crosslinkers. TPP and glutaraldehyde are the polyanions used. Owing to the reported toxic effects of glutaraldehyde, ${ }^{34}$ TPP is the chief polyanion used in the synthesis of chitosan NPs.

The synthesis of the chitosan particles is followed by the functionalization of the NP with $\alpha$-santalol, a potent bioactive sesquiterpene compound present in the essential oil of Santalum album (East Indian sandalwood tree). The heartwood and the oil of Santalum album have been extremely valued for centuries. They are used as flavor constituents in the food industry and also used in the manufacture of cosmetics and perfume due to their fragrance..$^{35}$ The major constituents of the essential oil of Santalum album comprise $\alpha$-santalol and $\beta$-santalol, ${ }^{36}$ which deliver a myriad of activities including antioxidant activity, stress modulation effects, ${ }^{36}$ antihyperglycemic activity, ${ }^{37}$ anti-viral activity ${ }^{38}$ and also have neuroleptic effects. ${ }^{37}$ Additionally, they have potent anti-cancer activity against breast cancer, ${ }^{39}$ skin cancer, ${ }^{40}$ and prostate cancer by impeding angiogenesis and also targeting the vascular endothelial growth factor (VEGF) receptor-mediated signaling pathway. ${ }^{\mathbf{4 1 , 4 2}}$

Hence, the present study was aimed at synthesizing and functionalizing chitosan NPs with $\alpha$-santalol to target the activity of the polo-like kinase in triple negative breast cancer cells and in vivo in xenograft mice as a competent approach for treating TNBC.

\section{Materials and methods}

\subsection{Materials}

The phyto bioactive principle $\alpha$-santalol was purchased from the Parchem Company private Ltd with a purity of $99 \%$.

\subsection{Method}

2.2.1. Synthesis of chitosan nanoparticles. The $\alpha$-santalol loaded chitosan NPs (Sn-CNPs) were fabricated using the ionotropic gelation technique reported by Elzatahry and Eldin in 2008 , with slight modifications. ${ }^{43}$ The synthesis involved the addition of an aqueous solution of sodium TPP $(18 \mathrm{~mL}, 1 \mathrm{mg}$ $\left.\mathrm{mL}^{-1}\right)$ in a drop-wise manner into a solution of chitosan $(35 \mathrm{~mL}$, $1 \mathrm{mg} \mathrm{mL}{ }^{-1}$ ) with and without $\alpha$-santalol $(10 \mathrm{mg} \mathrm{mL}$; dissolved in $0.1 \%$ DMSO). The chitosan solution was made by dissolving $1 \%$ $(\mathrm{v} / \mathrm{v})$ acetic acid and continuously stirring. The $\mathrm{pH}$ of the solution was adjusted to 4.6 using $0.1 \mathrm{~N} \mathrm{NaOH}$. The NPs were molded without any aggregation following continuous stirring overnight. After overnight stirring, the chitosan nanoparticles and Sn-CNPs were subjected to centrifugation at $10000 \mathrm{rpm}$ at $4{ }^{\circ} \mathrm{C}$. Subsequently, the supernatant was discarded, and the pellet was washed with $10 \%$ aqueous ethanol (Scheme 1) and preserved at $4{ }^{\circ} \mathrm{C}$ for further use.

2.2.2. Loading and encapsulation efficiency of $\alpha$-santalol. The Sn-CNPs were dispersed in phosphate buffer saline (PBS, 6 $\mathrm{mL}$ ) and centrifuged at $12000 \mathrm{rpm}$ for $30 \mathrm{~min}$. The supernatant was collected to measure the ultraviolet absorption at $280 \mathrm{~nm}$. The loading efficiency and encapsulation efficiency of $\alpha$-santalol in the chitosan NPs were calculated as follows:

$$
\begin{gathered}
\text { Loading efficiency }=W_{0} / W \times 100 \% \\
\text { Encapsulation efficiency }=W_{0} / W_{1} \times 100 \%
\end{gathered}
$$

where $W_{0}$ is the amount of $\alpha$-santalol loaded with the chitosan NPs, $W$ is the amount of chitosan NPs, and $W_{1}$ is the amount of chitosan added in the system.

2.2.3. In vitro $\alpha$-santalol release studies. The drug release profile of prepared Sn-CNPs was investigated at different $\mathrm{pH}$, namely 5.5, 6.8, and 7.4. The $\alpha$-santalol loaded chitosan nanoparticles were dispersed in PBS (pH 7.4) and transferred into a dialysis bag. The dialysis bag was immersed in PBS ( $95 \mathrm{~mL}$ ) at $\mathrm{pH}$ 5.5, 6.8, and 7.4 with continuous stirring. The drug release profile was done at $37^{\circ} \mathrm{C}$. About $5 \mathrm{~mL}$ of the aqueous solution was withdrawn and substituted with $5 \mathrm{~mL}$ of fresh PBS at constant time intervals. After the experiment, the dialysate samples were evaluated by assessing the absorbance at $280 \mathrm{~nm}$ for $\alpha$-santalol using UV-Vis spectroscopy.

\subsubsection{Characterization of functionalized chitosan nano-} particles with $\alpha$-santalol

2.2.4.1. UV-Vis spectral analysis. In order to confirm the formation of the NPs, the synthesized NPs were subjected to UVVis spectral analysis with the visible wavelengths covering a range from approximately 200 to $600 \mathrm{~nm}$, using a quartz cuvette.

2.2.4.2. FT-IR characterization. Fourier transform infrared (FT-IR) spectroscopy of the synthesized NPs was done with the help of a Nicolet 5700 instrument (Nicolet Instrument, Thermo Company, USA) by following the $\mathrm{KBr}$ pellet method. The synthesized NPs were ground with potassium bromide to form a translucent disc, which was then scanned over a wavelength range from $4000 \mathrm{~cm}^{-1}$ to $400 \mathrm{~cm}^{-1}$. 


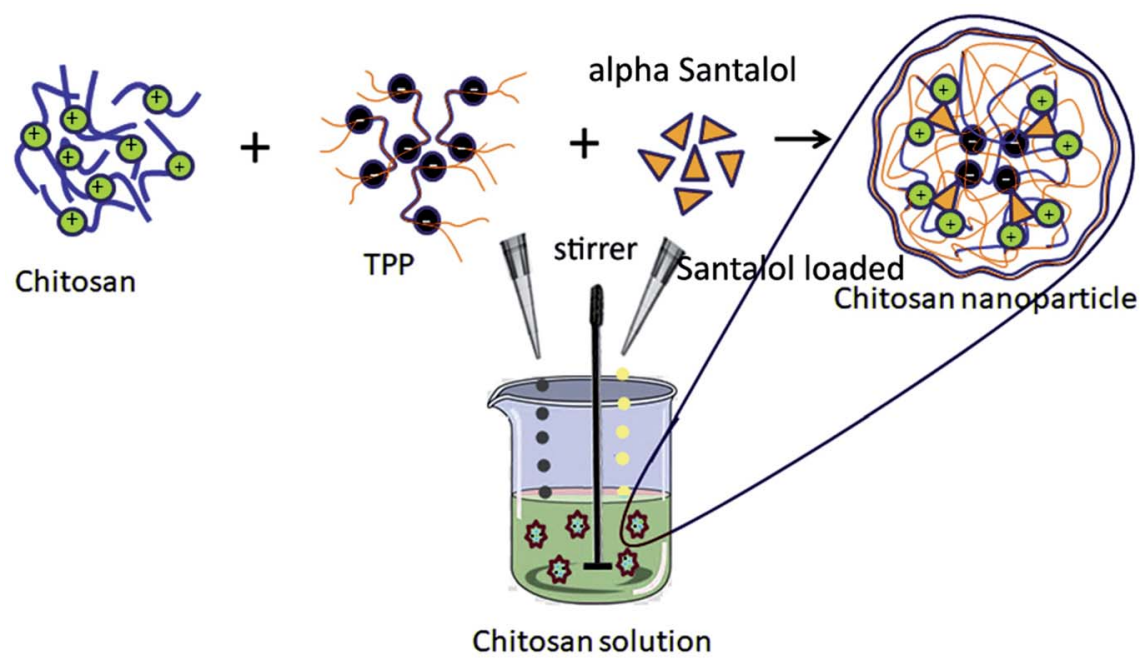

Scheme 1 Schematic illustration of the synthesis of $\alpha$-santalol loaded chitosan nanoparticles.

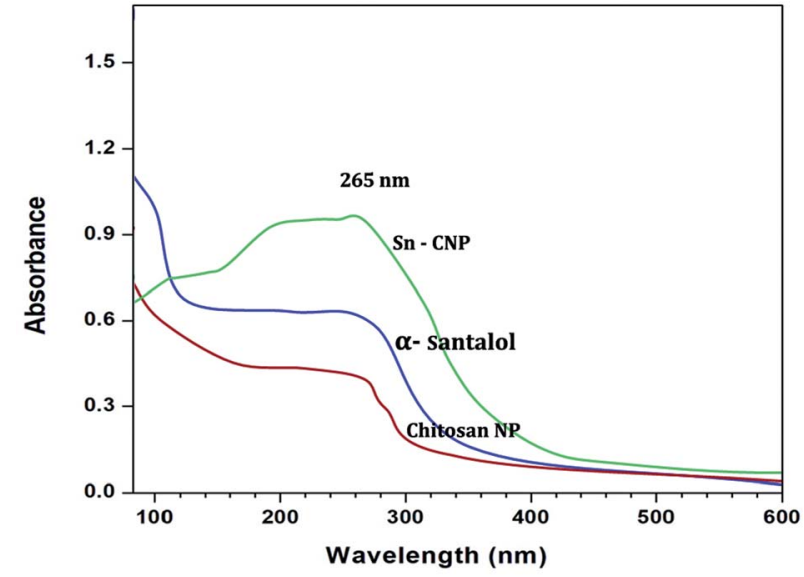

Fig. 1 UV-Vis spectral analysis of the synthesized nanomaterials.
2.2.4.3. Zeta potential analysis. The zeta potential of the synthesized chitosan NPs was determined by means of a zeta potential analyzer (90 Plus Particle Size Analyzer, Brookhaven Instruments Corporation, using Zeta plus software). The study was carried out at a scattering angle of $90^{\circ}$ and a temperature of $25{ }^{\circ} \mathrm{C}$ with the NPs dispersed in deionized distilled water. The determination of the zeta potential is based on the direction and velocity of the particles under the impact of a known electric field.

2.2.4.4. Dynamic light scattering (DLS) analysis. The particle size range of the synthesized chitosan NPs along with its distribution was determined using a particle size analyzer (90 Plus Particle Size Analyzer, Brookhaven Instruments Corporation). The particle size was determined based on measuring the time-dependent variation of laser light scattering by the NPs

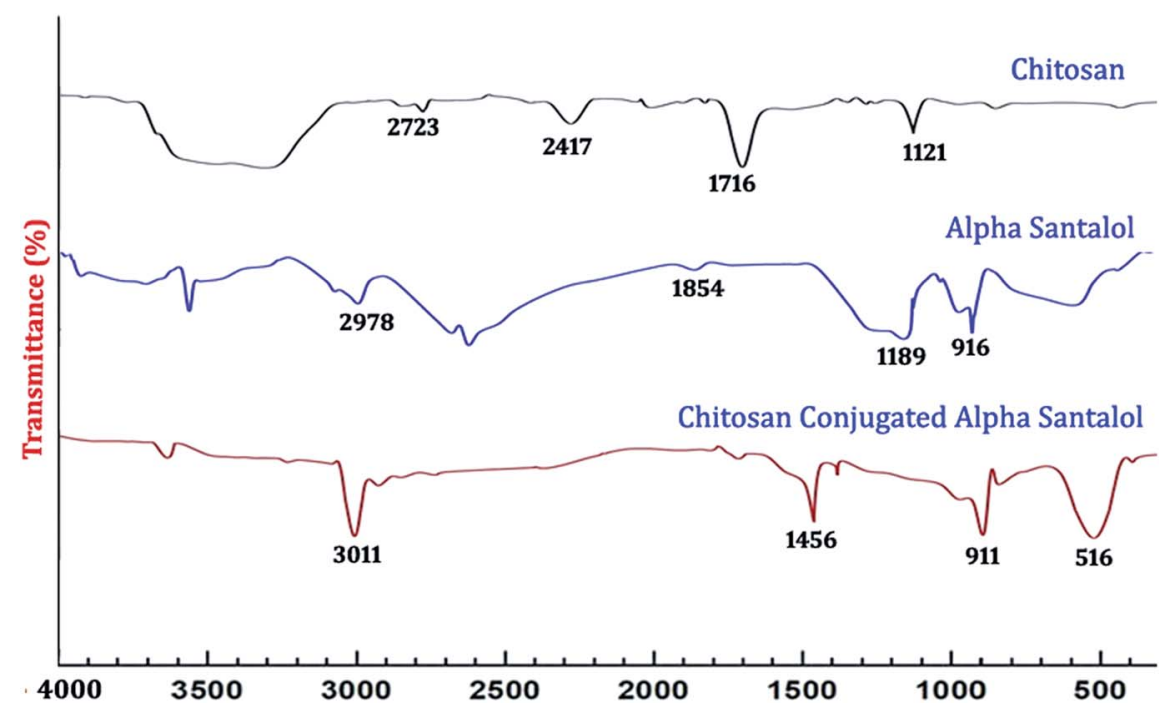

Fig. 2 FT-IR spectral analysis of the synthesized nanomaterials. 

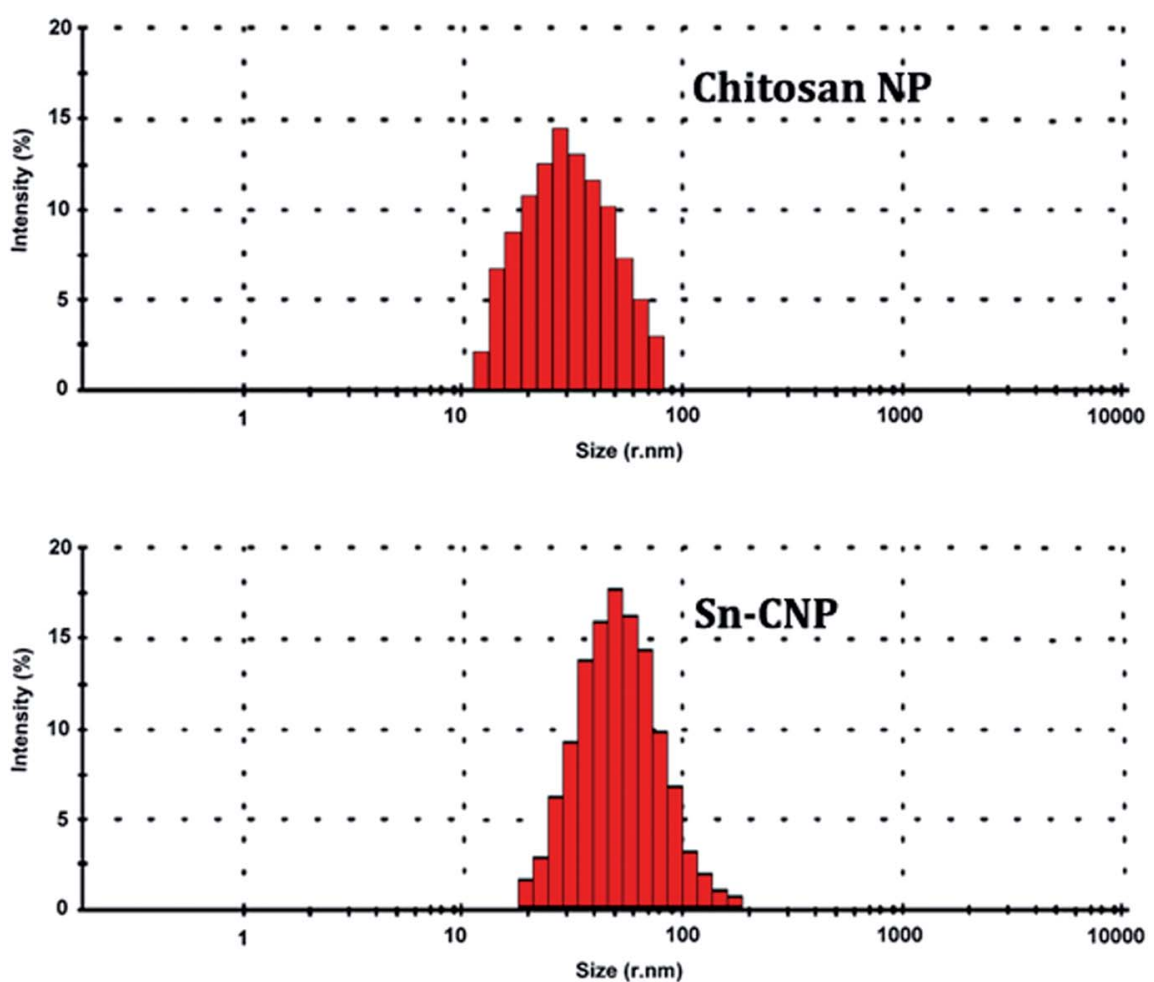

Fig. 3 Dynamic light scattering analysis of the synthesized nanomaterials.

undergoing Brownian movement. The distribution of the synthesized NPs was given as a polydispersity index (PDI).

2.2.4.5. Scanning electron microscopy (SEM) analysis. The synthesized chitosan NPs were placed on a polycarbonate substrate and the excess water was left to dry at room temperature. They were dried in a critical point dryer using carbon dioxide, sputter-coated with gold in a metallizer, and examined under a scanning electron microscope (JSM5600LV, JEOL, Japan) working at an accelerating voltage of $20 \mathrm{kV}$.

\subsection{In vitro study}

2.3.1. Cell culture. The triple negative breast cancer cell line, MM2 (MDA-MB-231), was procured from the National
Centre for Cell Sciences (NCCS), Pune, India. Subsequently, the cell line, MDA-MB-231, was maintained in Dulbecco's modified eagles medium (DMEM) supplemented with L-glutamine (2 $\mathrm{mM}$ ) and balanced salt solution (BSS) adjusted to contain glucose $\left(1.5 \mathrm{~g} \mathrm{~L}^{-1}\right), \mathrm{Na}_{2} \mathrm{CO}_{3}\left(1.5 \mathrm{~g} \mathrm{~L}^{-1}\right)$, sodium pyruvate $(1 \mathrm{Mm})$, non-essential amino acids $(0.1 \mathrm{mM})$, L-glutamine $(2 \mathrm{mM}),(4-(2-$ hydroxyethyl)-1-piperazineethane sulfonic acid) (HEPES, 10 $\mathrm{mM}$ ), and $10 \%$ fetal bovine serum (GIBCO, USA). Penicillin and streptomycin $(100 \mathrm{IU} / 100 \mu \mathrm{g})$ were adjusted to $1 \mathrm{~mL} \mathrm{~L}^{-1}$. The cells were maintained at $5 \% \mathrm{CO}_{2}$ with $37^{\circ} \mathrm{C} .{ }^{44}$

2.3.2. Evaluation of the cytotoxicity of the synthesized nanomaterial. In order to evaluate the inhibitory concentration $\left(\mathrm{IC}_{50}\right)$ value, an MTT (3-(4,5-dimethylthiazol-2-yl)-2,5-

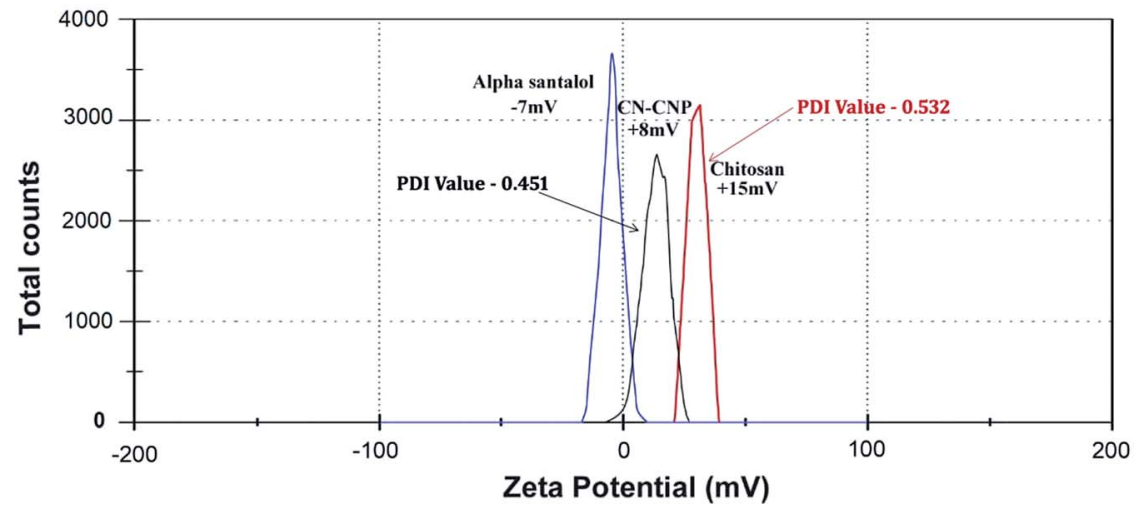

Fig. 4 Zeta potential analysis of the nanomaterials. 

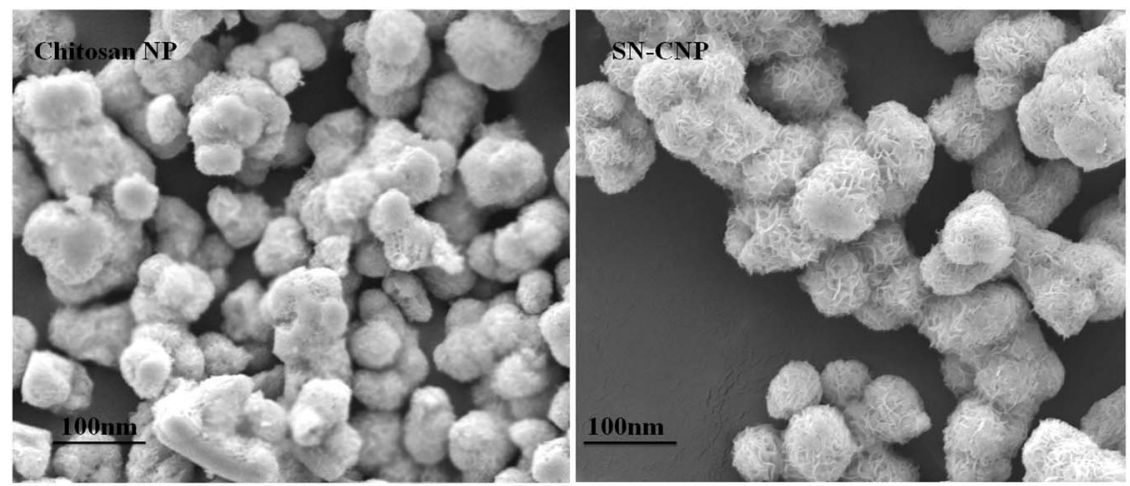

Fig. 5 Scanning electron microscopic analysis of chitosan NPs and $\alpha$-santalol loaded chitosan NPs.

Table 1 Loading efficiency and encapsulation efficiency of $\alpha$-santalol functionalized chitosan nanoparticles

\begin{tabular}{|c|c|c|c|}
\hline \multirow[b]{2}{*}{ Parameter } & \multicolumn{3}{|c|}{$\alpha$-Santalol concentration } \\
\hline & $1 \mu \mathrm{g} \mathrm{mL} L^{-1}$ & $4 \mu \mathrm{g} \mathrm{mL} L^{-1}$ & $8 \mu \mathrm{g} \mathrm{mL}{ }^{-1}$ \\
\hline Loading efficiency (\%) & $6.5 \pm 0.2$ & $8.5 \pm 0.5$ & $16.7 \pm 0.8$ \\
\hline Entrapment efficiency (\%) & $22 \pm 0.6$ & $46 \pm 0.2$ & $72 \pm 0.4$ \\
\hline
\end{tabular}

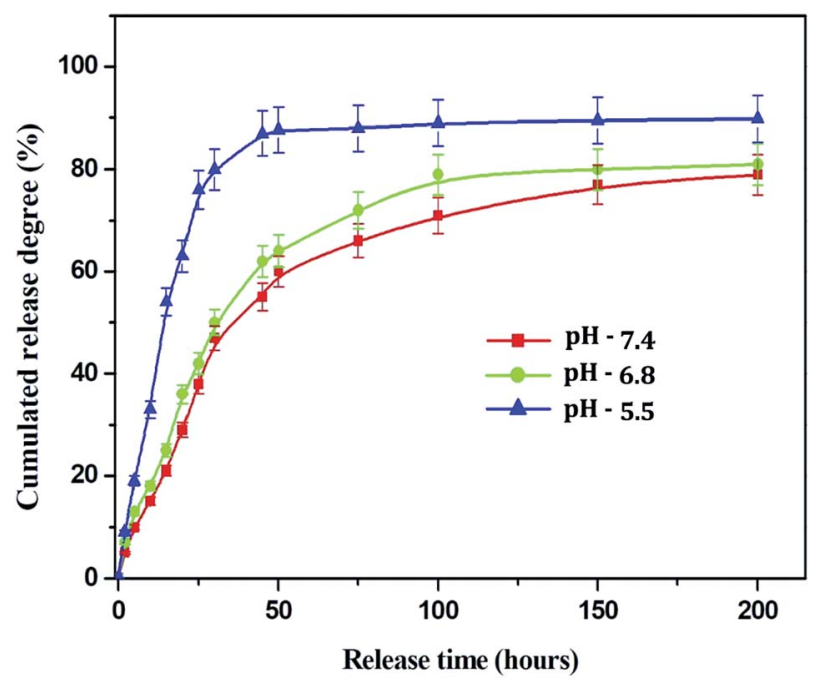

Fig. 6 Drug release profile of the Sn-CNPs at different $\mathrm{pH}$.

diphenyltetrazolium bromide, Hi-Media) assay was done. The MDA-MB-231 cells were grown $\left(1 \times 10^{4}\right.$ cells per well $)$ in a 96well plate for $48 \mathrm{~h}$ to get $80 \%$ cell confluence. The media was substituted with fresh media containing $\alpha$-santalol, chitosan NPs, and Sn-CNPs $\left(10,20,30,40\right.$, and $\left.50 \mu \mathrm{g} \mathrm{mL}^{-1}\right)$ and the cells were further incubated for $24 \mathrm{~h}$. The culture media was removed. MTT solution $(100 \mu \mathrm{L})$ was added to each well and the cells were incubated at $37^{\circ} \mathrm{C}$ for $4 \mathrm{~h}$. Then, the supernatant was removed. DMSO $(50 \mu \mathrm{L})$ was added to each well and the cells were incubated for $10 \mathrm{~min}$ to solubilize the formazan crystals. Using an ELISA multiwell plate reader (Thermo Multiskan EX, USA), the optical density was measured at $570 \mathrm{~nm}$ and it was then used to calculate the percentage viability, which has been given by the following formula: $:^{45}$

$$
\begin{gathered}
\% \text { viability }=(\mathrm{OD} \text { value of experimental sample/OD value of } \\
\text { experimental control }) \times 100
\end{gathered}
$$

2.3.3. Morphological study. The selected human MDA-MB231 cancer cells were allowed to culture on a cover slip $\left(1 \times 10^{5}\right.$ cells per cover slip) followed by incubation with $\alpha$-santalol, chitosan NPs, and Sn-CNPs $\left(\mathrm{IC}_{50}\right)$. They were fixed with an ethanol : acetic acid solution $(3: 1, \mathrm{v} / \mathrm{v})$. Three monolayers per experimental group were micrographed. Further, the morphometric analysis was carried out by gently mounting the cover slips on the glass slides and focused using a Nikon (Japan) bright field inverted light microscope at $40 \times$ magnification. $^{45}$

2.3.4. Fluorescence microscopic analysis of apoptotic cell death. Approximately $1 \mu \mathrm{L}$ of a dye mixture $\left(100 \mathrm{mg} \mathrm{mL}^{-1}\right.$ acridine orange $(\mathrm{AO})$ and $100 \mathrm{mg} \mathrm{mL} \mathrm{m}^{-1}$ ethidium bromide (EtBr) in distilled water) was mixed with $0.9 \mathrm{~mL}$ of the cell suspension $\left(1 \times 10^{5}\right.$ cells per $\left.\mathrm{mL}\right)$ on clean microscope cover slips. The pretreated cancer cells were collected, washed with PBS (pH 7.2) and stained with the AO/EtBr solution $(10 \mu \mathrm{L})$. After incubation for $2 \mathrm{~min}$, the cells were washed twice with PBS (5 min each) and visualized under a fluorescence microscope (Nikon Eclipse, Inc, Japan) at $400 \times$ magnification with an excitation filter of $580 \mathrm{~nm}$. Similarly, the cells were placed on glass coverslips in a 6-well plate and treated with $\alpha$-santalol, chitosan NPs, and Sn-CNPs $\left(\mathrm{IC}_{50}\right)$ for $24 \mathrm{~h}$. The fixed cells were permeabilised with $0.2 \%$ Triton X-100 $(50 \mu \mathrm{L})$ for $10 \mathrm{~min}$ at room temperature and incubated for 3 min with DAPI $(10 \mu \mathrm{L})$. The coverslip was placed above the cells, which allowed for an even distribution of the stain. The cells were observed under a fluorescence microscope (Nikon Eclipse, Inc, Japan). ${ }^{45}$

2.3.5. Detection of apoptosis by Annexin-V/FITC- flow cytometry. MDA-MB-231 cells $\left(1 \times 10^{5}\right)$ were seeded in a 6-well plate. After $24 \mathrm{~h}$ incubation at $37^{\circ} \mathrm{C}\left(5 \% \mathrm{CO}_{2}\right)$, the medium was changed with $\alpha$-santalol, chitosan NPs, and Sn-CNPs ( $\left.\mathrm{IC}_{50}\right)$. After $24 \mathrm{~h}$ incubation, the cells were harvested with trypsin, washed with PBS, and fixed in 70\% ethanol. They were stored at $-20{ }^{\circ} \mathrm{C}$ for $1 \mathrm{~h}$. The cellular nuclear DNA was stained with 

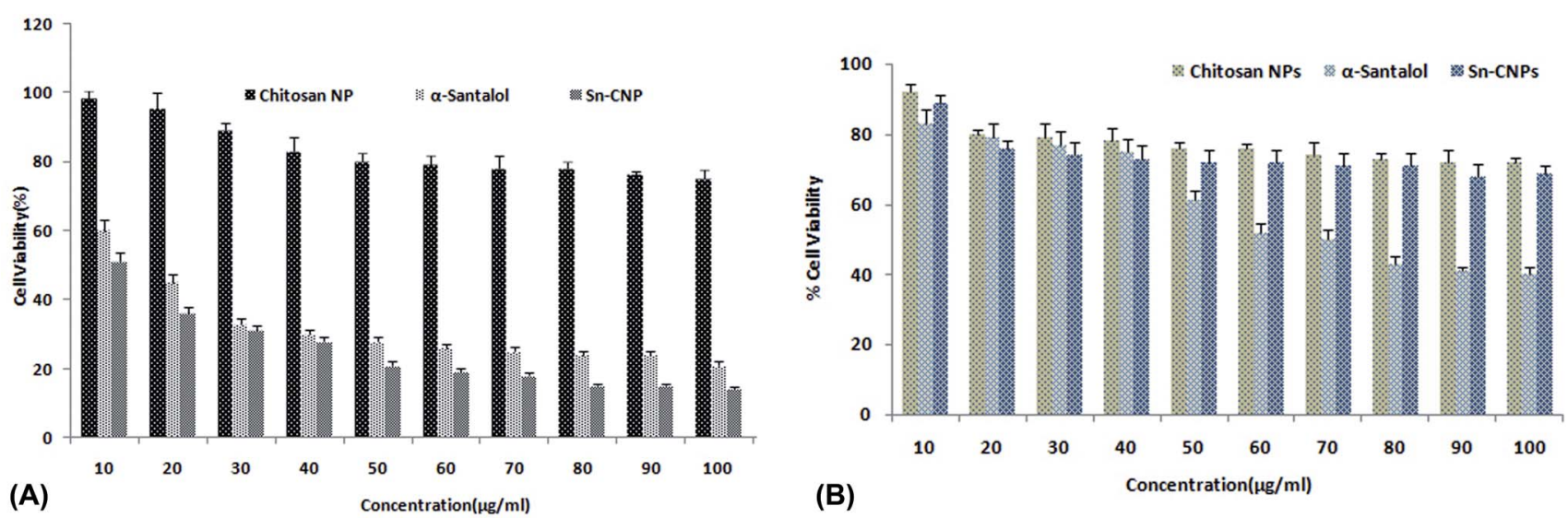

Fig. 7 (A) Cytotoxic analysis of the synthesized nanomaterials against triple negative breast cancer cells (MDA MB-231). (B) Cytotoxic analysis of the synthesized nanomaterials against normal breast cells (MCF-10).

annexin V-FITC as described, followed by incubation at $37{ }^{\circ} \mathrm{C}$ for $30 \mathrm{~min}$. Flow cytometry was performed in duplicate with a BD FACS Verse flow cytometer. From each sample, 10000 events were collected and fluorescence signal intensity was recorded and analyzed by CellQuest and Modifit.

\subsection{Western blotting}

Western blotting was performed to detect the regulation of apoptotic and anti-apoptotic proteins in treated cells. MDA-MB231 cells $\left(1.5 \times 10^{6}\right)$ were seeded onto $100 \mathrm{~mm} \times 20 \mathrm{~mm}$ culture dishes in the presence of $\alpha$-santalol, chitosan NPs, and Sn-CNPs $\left(5,10,20 \mu \mathrm{g} \mathrm{mL}^{-1}\right)$, and were treated for $24 \mathrm{~h}$. The medium was removed and the cells were washed with PBS (0.01 M, pH 7.2) several times. Following the removal of the supernatant solution, the cells were lysed with lysis buffer $(0.1 \mathrm{~mL}$ of lysis buffer for each plate) for $20 \mathrm{~min}$. The supernatants were collected by centrifugation at $10000 \mathrm{~g}$ for $5 \mathrm{~min}$ at $4{ }^{\circ} \mathrm{C}$ and were used as the cell protein extracts. The collected protein concentration was measured using a protein assay kit. The same amount of protein from each sample was applied to $12 \%$ SDS-polyacrylamide gel electrophoresis. Proteins were shifted onto a nitrocellulose membrane and then blocked for $1 \mathrm{~h}$ by means of $10 \%$ skimmed milk in water. After washing with PBS containing $0.1 \%$ Tween 20 for three times, primary antibodies against BAD, BAX, caspase 3 , caspase $9, \mathrm{Bcl}-2, \beta$-actin, and PLK-1 were added at a v/v ratio of $1: 1000$. Subsequently, the samples were incubated overnight at $4{ }^{\circ} \mathrm{C}$, and then the primary antibodies were washed. This was followed by the addition of the secondary antibodies after $1 \mathrm{~h}$ incubation at room temperature. Then the protein bands were analyzed.

\subsection{RT-PCR}

The MDA-MB-231 cells were treated in the presence of $\alpha$-santalol, chitosan NPs, and Sn-CNPs $\left(5,10,20 \mu \mathrm{g} \mathrm{mL}^{-1}\right)$, and also an untreated control was set up. After $24 \mathrm{~h}$ of treatment, the media was removed. TriZol reagent was used to quarantine total RNA and it was reverse transcribed. The cDNA was isolated using the cDNA synthesis kit and amplified according to the instructions. RT-PCR analysis for quantifying the apoptotic genes was performed in a $20 \mu \mathrm{L}$ reaction mixture containing random primer pairs (forward and reverse $0.5 \mu \mathrm{L}+0.5 \mu \mathrm{L})(1.0$ $\mu \mathrm{L}), 10 \times$ reaction buffer containing a master mix $\left(25 \mathrm{mM} \mathrm{L}^{-1}\right.$ $\mathrm{MgCl}_{2}, 10 \mathrm{mM} \mathrm{L}{ }^{-1} \mathrm{dNTPs}$, Taq polymerase $\left.2.5 \mathrm{U}\right)(10 \mu \mathrm{L})$, cDNA as a template $(2 \mu \mathrm{L})$ and the remaining volume was nuclease free $\mathrm{dH}_{2} \mathrm{O}(7 \mu \mathrm{L})$. Amplification cycles consisted of denaturation at $94{ }^{\circ} \mathrm{C}$ for $1 \mathrm{~min}$, primer annealing at $55^{\circ} \mathrm{C}$ for 40 seconds and extension at $72{ }^{\circ} \mathrm{C}$ or $1 \mathrm{~min}$, for a total of 32 cycles followed by a final extension at $72{ }^{\circ} \mathrm{C}$ for $10 \mathrm{~min}$.

\subsection{In vivo study}

2.6.1. In vivo assessment of anti-tumor activity. This study was performed in strict accordance with the NIH guidelines for the care and use of laboratory animals (NIH Publication No. 8523 Rev. 1985), and was approved by the Institutional Animal Care and Use Committee of Bharathiar University (IAEC, 722/ Go/Re/S/02/CPCSEA - India). Additionally, in this study, no

Table 2 Cytotoxic activity of the synthesized nanomaterials ( $\mu \mathrm{g} \mathrm{mL}^{-1}$ )

Cytotoxic activity of sample $\left(\mu \mathrm{g} \mathrm{mL}^{-1}\right)$

\begin{tabular}{ll} 
Nanomaterials & MDA MB 231 (triple negative breast cancer) \\
\hline Chitosan NPs & Insignificant toxicity up to $80 \mu \mathrm{g} \mathrm{mL}^{-1}$ \\
$\alpha$-Santalol & $15 \pm 1.0$ \\
Sn-CNP & $8.0 \pm 0.7$
\end{tabular}

MCF-10A (normal breast cells)

Insignificant toxicity up to $80 \mu \mathrm{g} \mathrm{mL} \mathrm{m}^{-1}$ Insignificant toxicity up to $70 \mu \mathrm{g} \mathrm{mL} \mathrm{L}^{-1}$ Insignificant toxicity up to $80 \mu \mathrm{g} \mathrm{mL}$ 

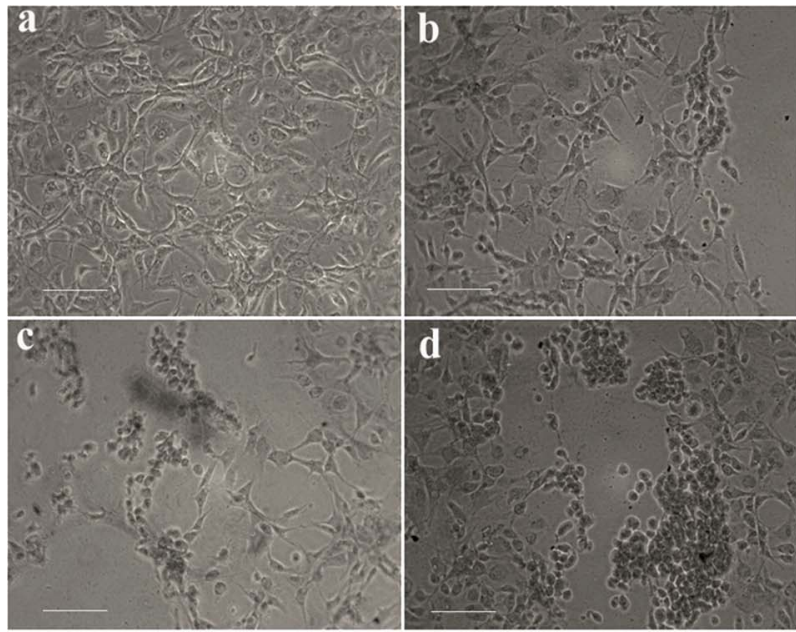

(A)

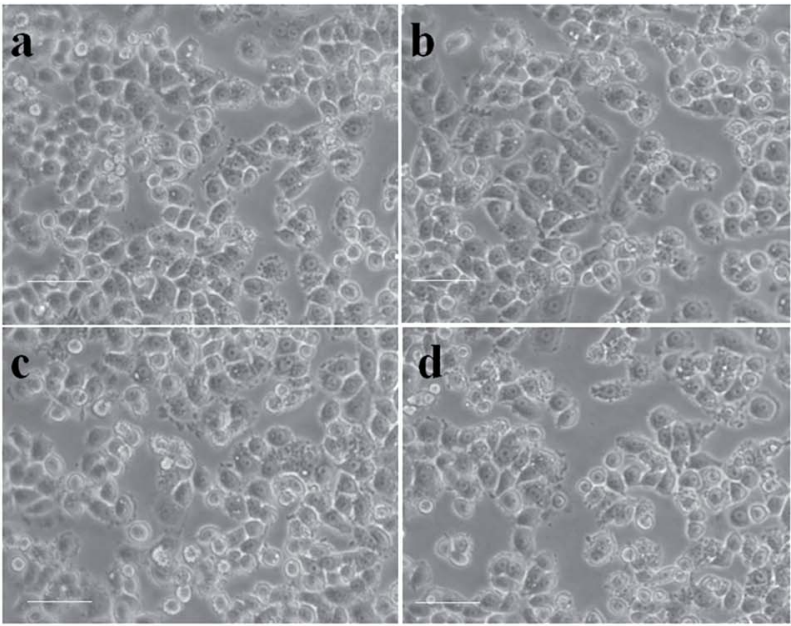

(B)

Fig. 8 (A) Morphometric analysis of the synthesized nanomaterials on MDA-MB-231 cells under an inverted microscope (a) control (b) $100 \mu \mathrm{g}$ $\mathrm{mL}^{-1}$ of chitosan NPs (c) $13 \mu \mathrm{g} \mathrm{mL}^{-1}$ of $\alpha$-santalol (d) $5 \mu \mathrm{g} \mathrm{mL}^{-1}$ of SnCNP treated cells. The scale bar measures about $100 \mu \mathrm{m}$. (B) Morphometric analysis of the synthesized nanomaterials on MCF-10A cells under an inverted microscope (a) control; (b) $100 \mu \mathrm{g} \mathrm{mL}^{-1}$ of chitosan NPs; (c) $50 \mu \mathrm{g} \mathrm{mL}^{-1}$ of $\alpha$-santalol; (d) $100 \mu \mathrm{g} \mathrm{mL}^{-1}$ of Sn-CNP treated cells. The scale bar measures about $100 \mu \mathrm{m}$.

informed consent human subjects were used. In vivo acute toxicity was assessed with young and healthy, non-pregnant, nulliparous swiss albino mice, weighing about 25-28 g (8 weeks old), which were placed in clean polypropylene cages with access to food and water by following OECD guidelines (OECD, 2001). These cages were placed in an air-conditioned animal house with a relative humidity of about $65-80 \%$ and at a temperature of $26-28{ }^{\circ} \mathrm{C}$ with $12 \mathrm{~h}$ light-dark cycles. The animals were acclimatized for one week by feeding with mice pellets, which are commercially available, and they were also given deionized water.

The efficacy of the compound against the tumor was assessed by implanting the tumor in the mice. This can be done by introducing the MDA-MB-231 cells $\left[1 \times 10^{7}\right.$ in $100 \mathrm{~mL}$ of
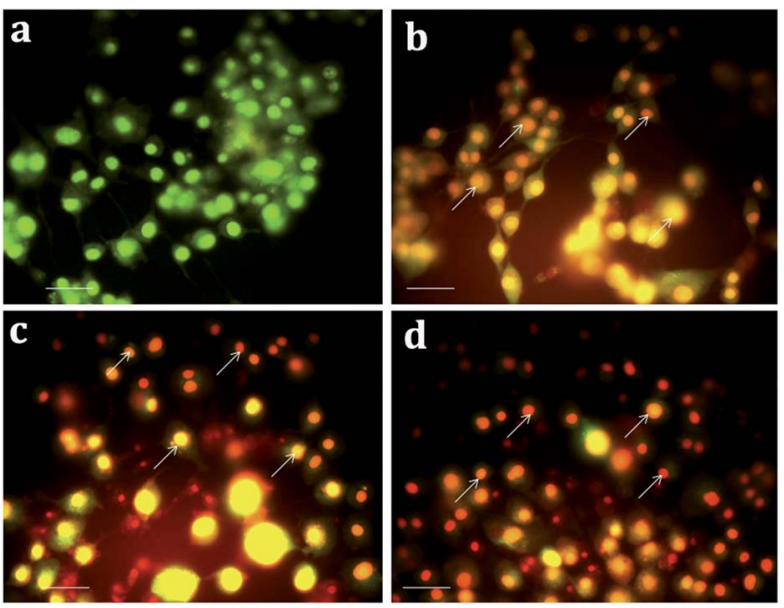

Fig. 9 Apoptotic analysis of the synthesized nanomaterials on MDAMB-231 cells under a fluorescence microscope (a) control; (b) $100 \mu \mathrm{g}$ $\mathrm{mL}^{-1}$ of chitosan NPs; (c) $13 \mu \mathrm{g} \mathrm{mL} \mathrm{m}^{-1}$ of $\alpha$-santalol; (d) $5 \mu \mathrm{g} \mathrm{mL}^{-1}$ of SnCNP treated cells. The scale bar measures about $100 \mu \mathrm{m}$ and the white arrows indicate apoptotic bodies.

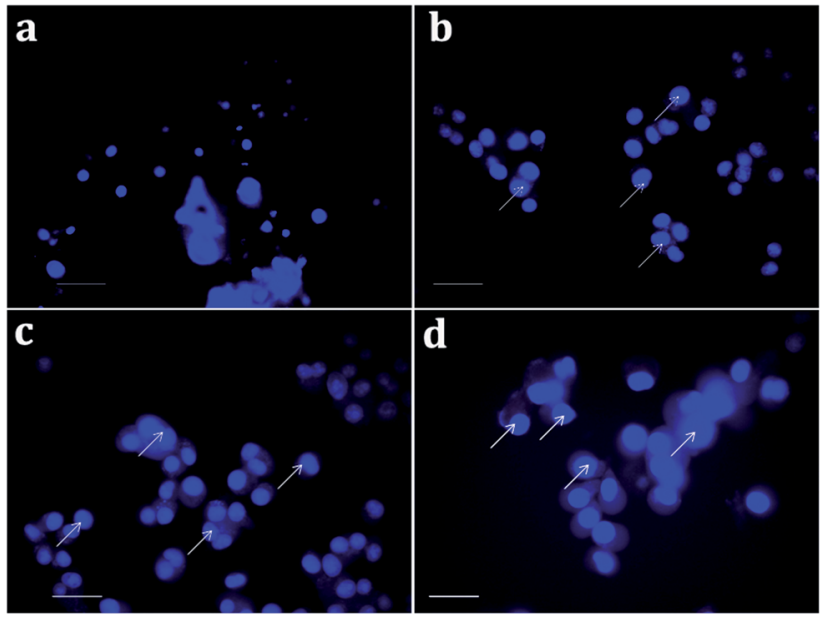

Fig. 10 Nuclear fragmentation analysis of the synthesized nanomaterials on MDA-MB-231 cells (a) control; (b) $100 \mu \mathrm{g} \mathrm{mL}^{-1}$ of chitosan NPs; (c) $13 \mu \mathrm{g} \mathrm{mL} \mathrm{g}^{-1}$ of $\alpha$-santalol (d) $5 \mu \mathrm{g} \mathrm{mL} \mathrm{L}^{-1}$ of Sn-CNP treated cells. The scale bar measures about $100 \mu \mathrm{m}$ and the white arrows indicate nuclear fragmented cells.

normal saline] to the subcutaneous dorsa of the mice. When the size of the xenograft tumor reached about $40-60 \mathrm{~mm}^{3}$, the mice were randomly segregated into 5 groups with 5 mice in each group: Group 1- mice treated with PBS (negative control), Group 2- mice treated with Doxorubicin (positive control), Group 3mice treated with chitosan NPs $\left(10 \mathrm{mg} \mathrm{mL}^{-1}\right)$, Group 4- mice treated with $\alpha$-santalol ( $8 \mathrm{mg} \mathrm{mL}^{-1}$ ), Group 5- mice treated with Sn-CNPs $\left(5 \mathrm{mg} \mathrm{mL}{ }^{-1}\right)$. The agents were administered to the mice through intravenous injection and the mice were then observed for 21 days. At three day intervals, the diameters of the tumors were measured for each animal group. The body weight and tumor volumes $(V)$ were calculated using the formula $V=$ length $\times(\text { width })^{2} / 2$. Histopathological analysis (brain, heart, 

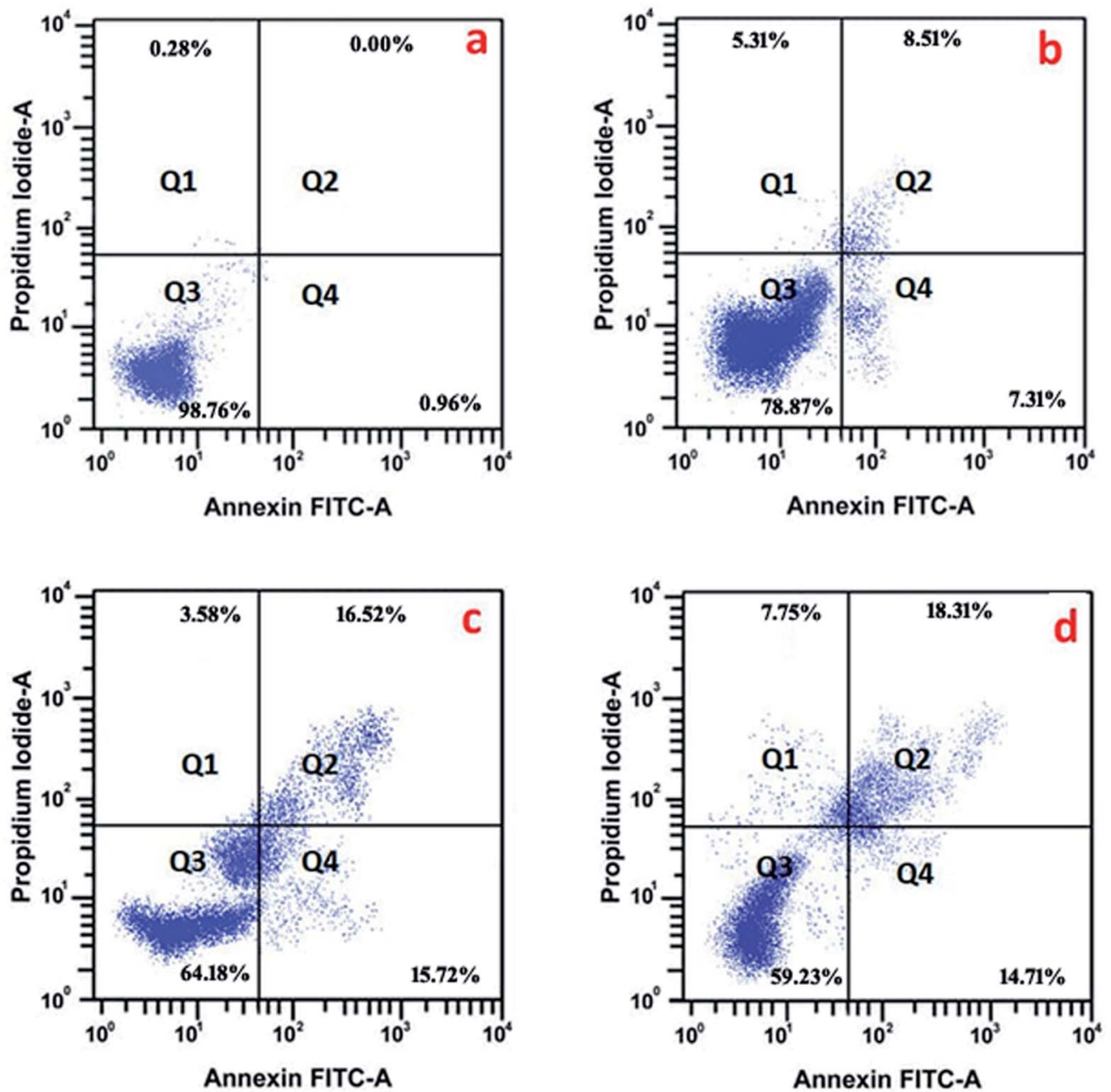

Fig. 11 Apoptotic analysis of the synthesized nanomaterials by flow cytometry on MDA-MB-231 cells; (a) control; (b) $100 \mu \mathrm{g} \mathrm{mL}{ }^{-1}$ of chitosan NPs; (c) $13 \mu \mathrm{g} \mathrm{mL}^{-1}$ of $\alpha$-santalol; (d) $5 \mu \mathrm{g} \mathrm{mL}^{-1}$ of Sn-CNP treated cells. In the panel I, II, III, and IV refer to necrotic cells, late apoptotic cells, proapoptotic cells, and live cells, respectively.

kidney, lung, and liver) was done following animal sacrifice by cerebral dislocation. Tissue slides were prepared and stained with hematoxylin and eosin stain (H and E stain). Further, they were visualized under a light microscope.

2.6.2. Hematological and biochemical parameters. The whole blood was centrifuged at $3000 \mathrm{rpm}$ for $15 \mathrm{~min}$ in order to obtain the serum. Serum biochemical levels including total cholesterol, total protein (TP), alkaline phosphatase (ALP), uric acid, tri-glyceride (TG), blood urea nitrogen (BUN), serum glutamic oxaloacetic acid (SGOT), and serum glutamic pyruvic transaminase (SGPT) were examined. $0.1 \mathrm{~mL}$ of $15 \mathrm{~g} \mathrm{~L}^{-1}$ EDTA$\mathrm{Na}$ was pre-added into a $1 \mathrm{~mL}$ blood sample and the blood sample was used for the blood element test within $2 \mathrm{~h}$. The blood-elements, including total count of red blood cells (RBCs), white blood cells (TC), dendritic cells (neutrophils, lymphocytes, monocytes, eosinophils, and basophils), and blood platelets were assayed.

2.6.3. Hemolytic assay. Hemolytic assays were done on the collected blood, which was maintained using the stabilizing agent, ethylenediaminetetraacetic acid (EDTA). To PBS $(8 \mathrm{~mL})$, blood $(4 \mathrm{~mL})$ was added. This was followed by centrifugation at
$10000 \mathrm{rpm}$ for $5 \mathrm{~min}$ in order to isolate the RBCs and further washing five times with sterile PBS solution. Then the RBCs were diluted with PBS $(40 \mathrm{~mL})$. Subsequently, the diluted RBC suspension $(0.2 \mathrm{~mL})$ was added to a concentration of 5,10 or 20 $\mu \mathrm{g} \mathrm{mL}^{-1}$ of $\alpha$-santalol, chitosan NPs, and Sn-CNPs, respectively. The sample vials were kept without disturbance for $3 \mathrm{~h}$ at room temperature. Finally, the vials were centrifuged at $10000 \mathrm{rpm}$ for $3 \mathrm{~min}$ and $100 \mu \mathrm{L}$ of supernatant from all samples were taken. Absorbance was noticed at $543 \mathrm{~nm}$. The percentage of hemolytic activity was calculated using the following formula:

$$
\begin{aligned}
\text { Hemolysis } \%= & \frac{\text { sample absorbance }- \text { negative control }}{\text { positive control }- \text { negative control }} \\
& \times 100
\end{aligned}
$$

Here, the deionized water and PBS with RBCs were used as positive and negative controls.

\subsection{Statistical analysis}

The data was analyzed using the SPSS software. The results are presented as mean \pm SD. Differences among various groups 


\section{Control CNPs $\quad \alpha$-Santalol Sn-CNP}

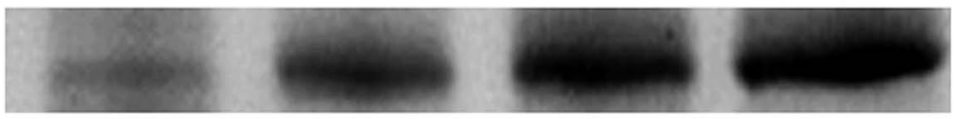

Bad

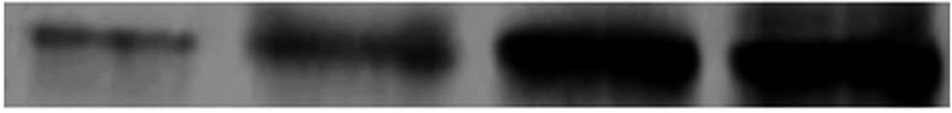

Bax

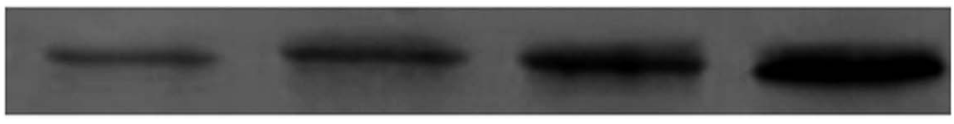

Caspase 3

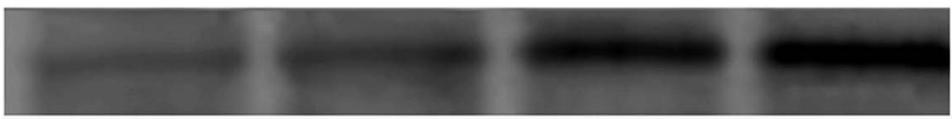

Caspase 9

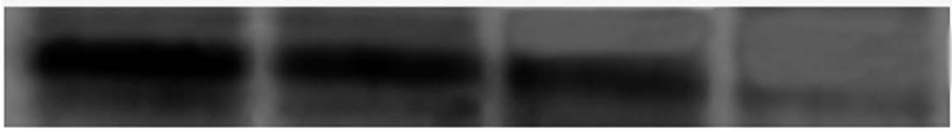

Bcl -2

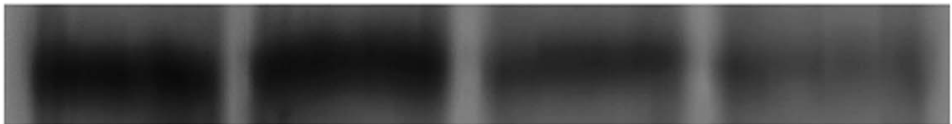

PLK-1
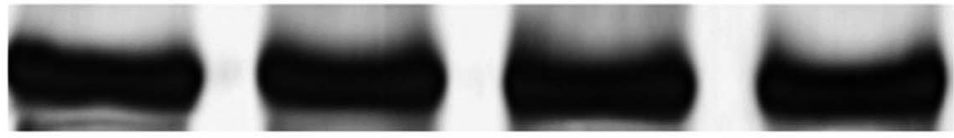

\section{$\beta$-actin}

Fig. 12 Expression of apoptotic and anti-apoptotic proteins by western blotting in MDA-MB-231 cells treated with the synthesized nanomaterials.

were evaluated by conducting one-way analysis of variance (ANOVA); $P<0.05$ were considered statistically significant groups.

\section{Result and discussion}

\subsection{Characterization of synthesized nanoparticle}

3.1.1. UV-Vis spectra and FTIR analysis. The UV-Vis spectra of the synthesized nanoparticles are depicted in Fig. 1. The absorption peaks of chitosan NPs, $\alpha$-santalol and Sn-CNPs were found to be at 265, 261, and $260 \mathrm{~nm}$, respectively. The specific absorption peaks may be due to the presence of amide groups in the particles. Krishnaveni et al. in $2014^{46}$ had obtained an absorption signal at $310 \mathrm{~nm}$ for a chitosan NP while Biswapriya et al. reported the spectrum of $\alpha$-santalol with a signal at $226 \mathrm{~nm}$. The FTIR spectrum of the synthesized NPs is presented in Fig. 2 and depicts the organic functional group present on the surface of the NPs. The peaks of chitosan NPs at $2723 \mathrm{~cm}^{-1}$, $2417 \mathrm{~cm}^{-1}$, and $1716 \mathrm{~cm}^{-1}$ are recognized as stretching vibrations of $\mathrm{C}-\mathrm{H}$ alkanes and the bending vibration at $1121 \mathrm{~cm}^{-1}$ is the fingerprint peak of chitosan, while the peak at $3375 \mathrm{~cm}^{-1}$ corresponds to $\mathrm{NH}_{2}$ and $\mathrm{OH}$ stretching vibrations. ${ }^{47,48}$ The $\alpha$ santalol has peaks at $2978 \mathrm{~cm}^{-1}$ and $1854 \mathrm{~cm}^{-1}$, which depict the presence of $\mathrm{O}-\mathrm{H}$ groups, $\mathrm{C}=\mathrm{H}$ groups, and aromatic rings. The synthesized Sn CNP shows the corresponding peaks of $576 \mathrm{~cm}^{-1}, 911 \mathrm{~cm}^{-1}$ represent the santalol coated particles remains have its bending vibrations with both the chitosan NPs and $\alpha$-santalol.

3.1.2. DLS and zeta potential analysis. The hydrodynamic diameter and surface charge of the synthesized NPs have a vital role in particle characterization and can be measured by DLS and a zeta sizer (Fig. 3 and 4). They give the dispersity, size, and charge of the NP. The size of the synthesized chitosan NPs and Sn-CNPs, shown in Fig. 3, were found to be $30 \mathrm{~nm}$ and $45 \mathrm{~nm}$, respectively. The polydispersity of the synthesized NPs was also noted. The average size of the NP largely depends on the concentration of the chitosan and TPP used during the production process. The results obtained clearly state that the zeta potential of the synthesized Sn-CNPs was found to be $+8 \mathrm{mV}$. In terms of dispersity index, the synthesized biomaterials are highly polydispersed in nature with multiple particle size populations. The polydispersion index values of the materials were determined to be about 0.451 for chitosan and 0.532 for Sn-CNPs, respectively. The higher positive charge of the potential indicates that the NPs are highly stable. ${ }^{49}$ A report by Blanco et $a l .{ }^{50}$ highlighted that positively charged NPs can effectively target the tumor environment when compared to NPs with other net charges.

3.1.3. SEM analysis. The SEM images highlight the size and morphology of the synthesized NPs. The size of the synthesized chitosan NPs and Sn-CNPs were found to be $30 \mathrm{~nm}$ and $45 \mathrm{~nm}$, respectively, while the particles were found to be spherical in shape (Fig. 5). The feathery appearance of the particles may be 


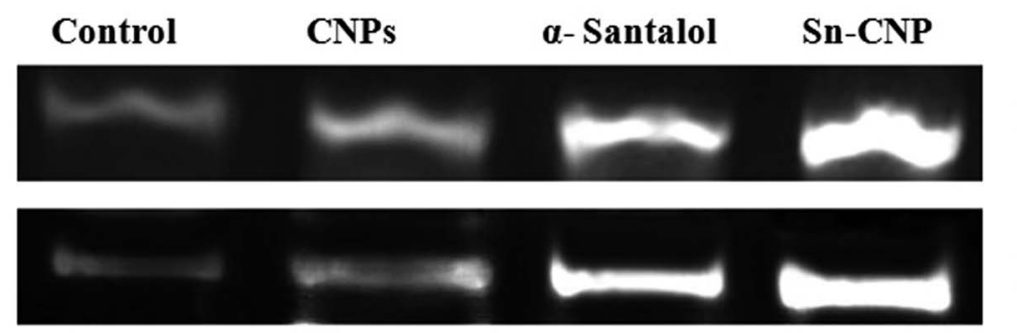

Bad

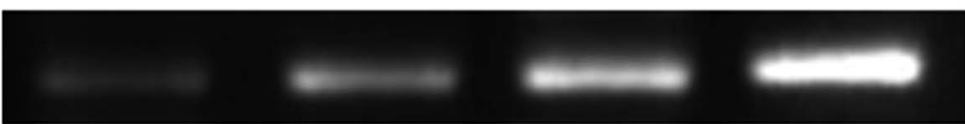

\section{Caspase 3}

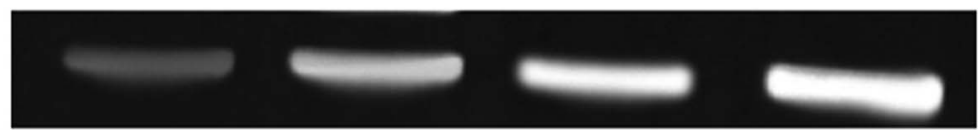

\section{Caspase 9}

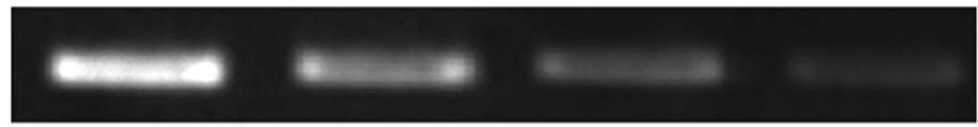

Bcl -2

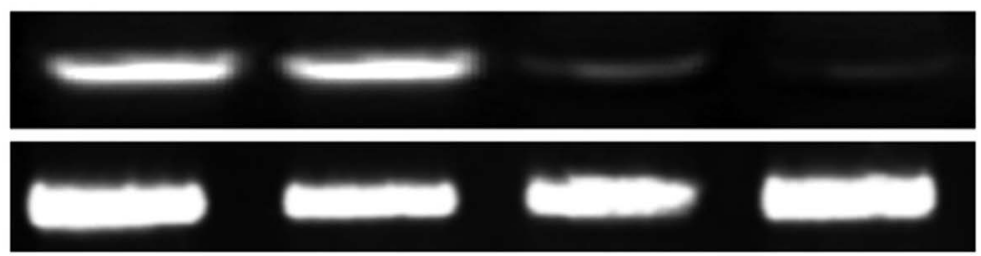

\section{PLK-1}

\section{$\beta$-actin}

Fig. 13 Expression of apoptotic and anti-apoptotic genes by RT-PCR analysis in MDA-MB-231 cells treated with the synthesized nanomaterials.
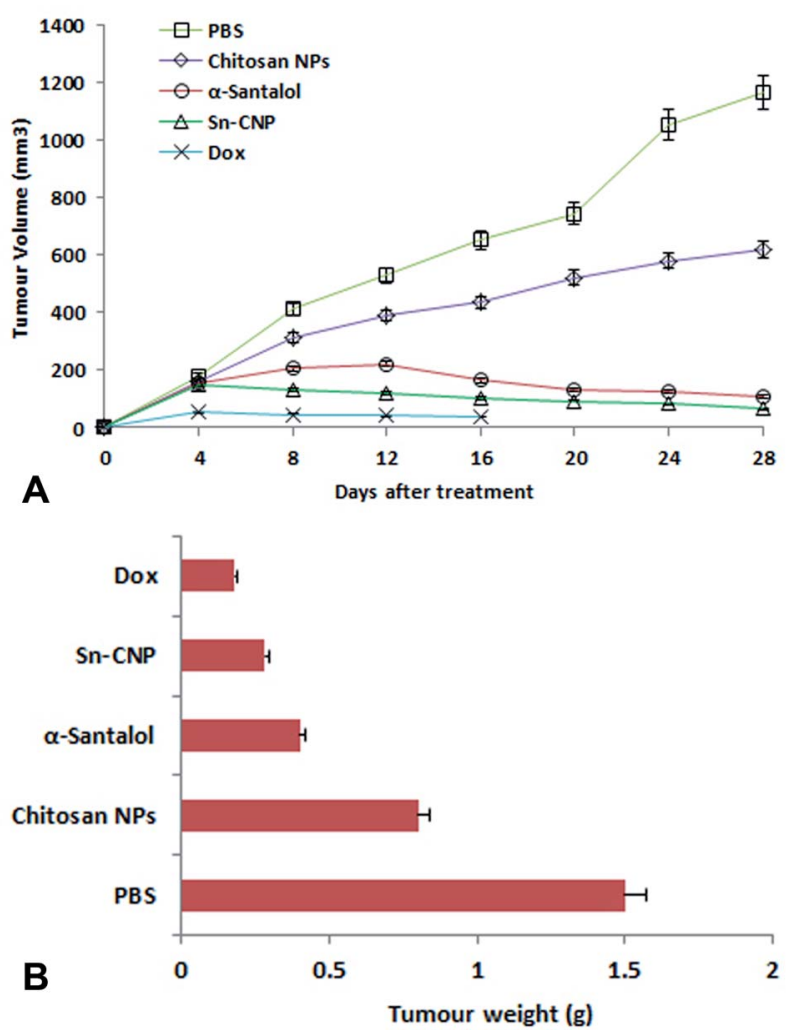

Fig. 14 (A) Effect of the synthesized nanomaterials on tumor volume. (B) Effect of the synthesized nanomaterials on tumor weight. due to the firm conjugation of the santalol molecule on the surface of the chitosan NPs. Since the size of the NPs were found to be less than $100 \mathrm{~nm}$, they have a greater capacity for accumulating in the tumor environment. ${ }^{51}$

3.1.4. Loading and encapsulation efficiency of $\alpha$-santalol. The loading and encapsulation efficiency of $\alpha$-santalol in the chitosan NPs is depicted in Table $1 . \alpha$-Santalol at three different concentrations $\left(1,4\right.$, and $\left.8 \mu \mathrm{g} \mathrm{mL} \mathrm{m}^{-1}\right)$ was used in the study. The loading and encapsulation efficiency is based on the highest concentration of $8 \mu \mathrm{g} \mathrm{mL} \mathrm{m}^{-1}$ with values of $16.7 \%$ and $72 \%$, respectively.

3.1.5. Drug release profile of Sn-CNPs. One of the most substantial characteristics of a drug delivery vehicle is its ability to release the payload drug efficiently into target cells. The drug release profile of the Sn-CNPs was recorded from $0 \mathrm{~h}$ up to $200 \mathrm{~h}$ under different $\mathrm{pH}$ conditions, namely $\mathrm{pH} 7.4$ (the $\mathrm{pH}$ of blood), pH 6.8 (the pH of cancer cells), and pH 5.5 (the pH in the tumor microenvironment). An in vitro $\alpha$-santalol release profile of the Sn-CNPs in PBS is shown in Fig. 6. The release rate decreased with increasing $\mathrm{pH}$ values. The results clearly demonstrated that Sn-CNPs revealed $\mathrm{pH}$-responsive release behavior. Approximately $90 \%$ of the combined $\alpha$-santalol was released from the loaded chitosan NPs in PBS at pH 5.5, at the maximum period of $200 \mathrm{~h}$. At $\mathrm{pH} 6.8$, the drug release ratio was slightly lower than that of $\mathrm{pH}$ 5.5. However, a prompt release happened at $\mathrm{pH} 7.4$, where more than $70 \%$ of the entrapped $\alpha$-santalol was released after an incubation period, which may be attributed to the acidic $\mathrm{pH}$-induced deformation of the linkage between $\alpha$ - 


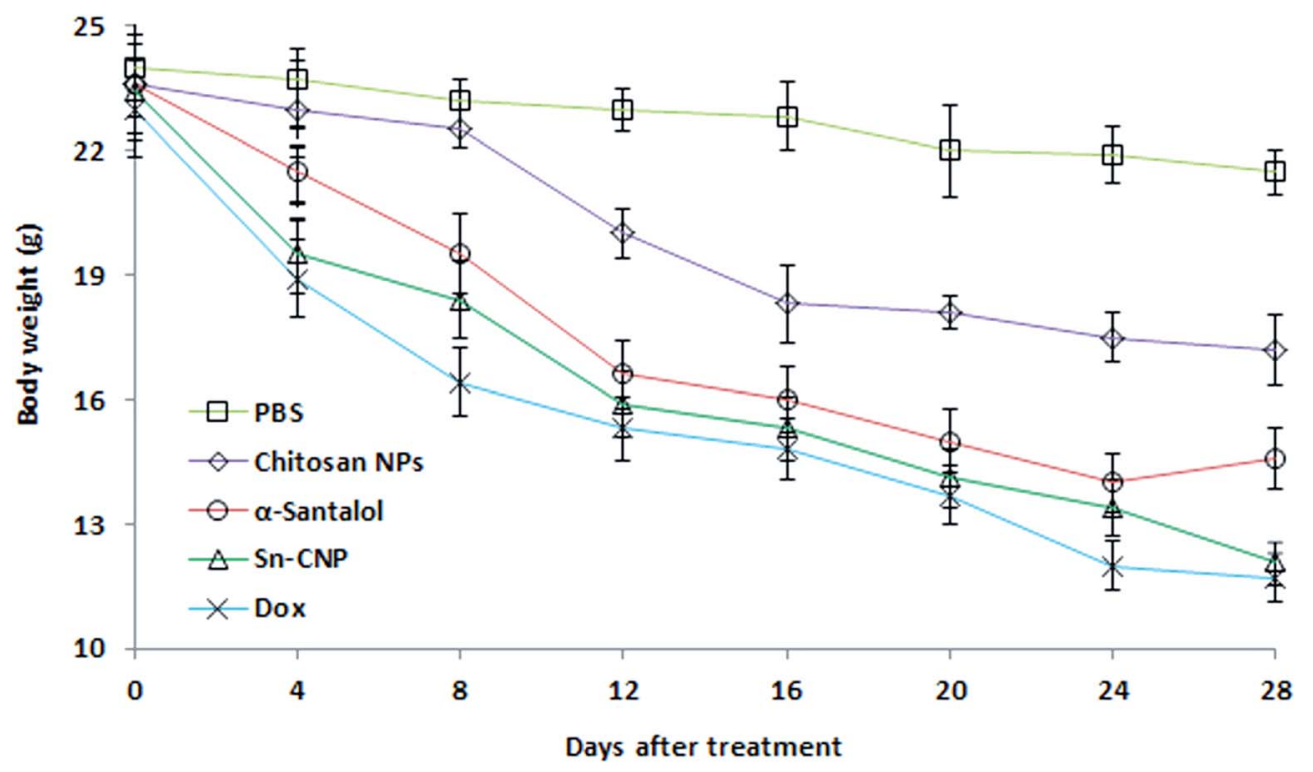

Fig. 15 Effect of the synthesized nanomaterials on the body weight of the mice.

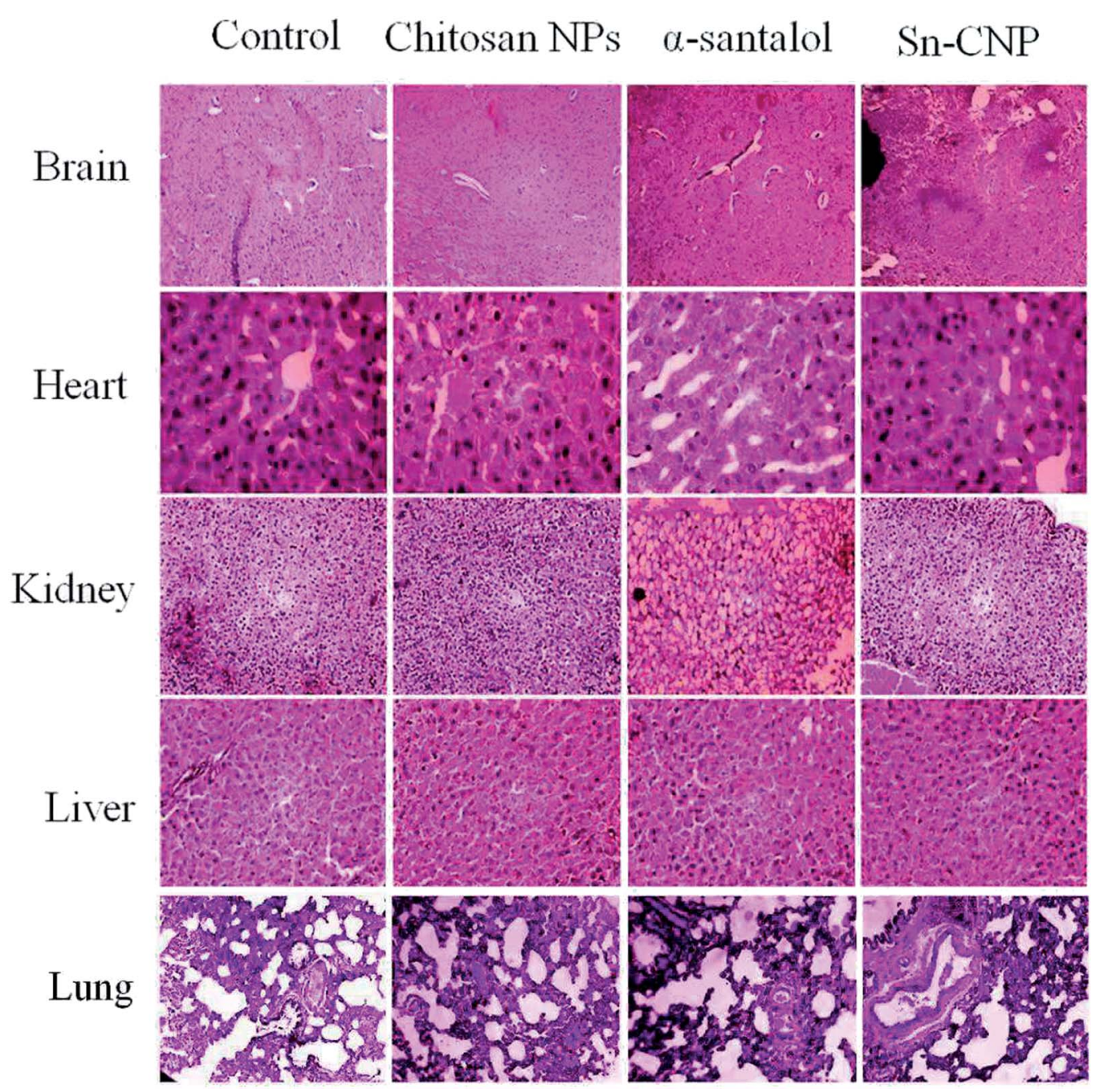

Fig. 16 Histopathological analysis of the treated mice groups with the synthesized nanomaterials. 
Table 3 A comparison of the hematological and biochemical parameters of the treated mice groups

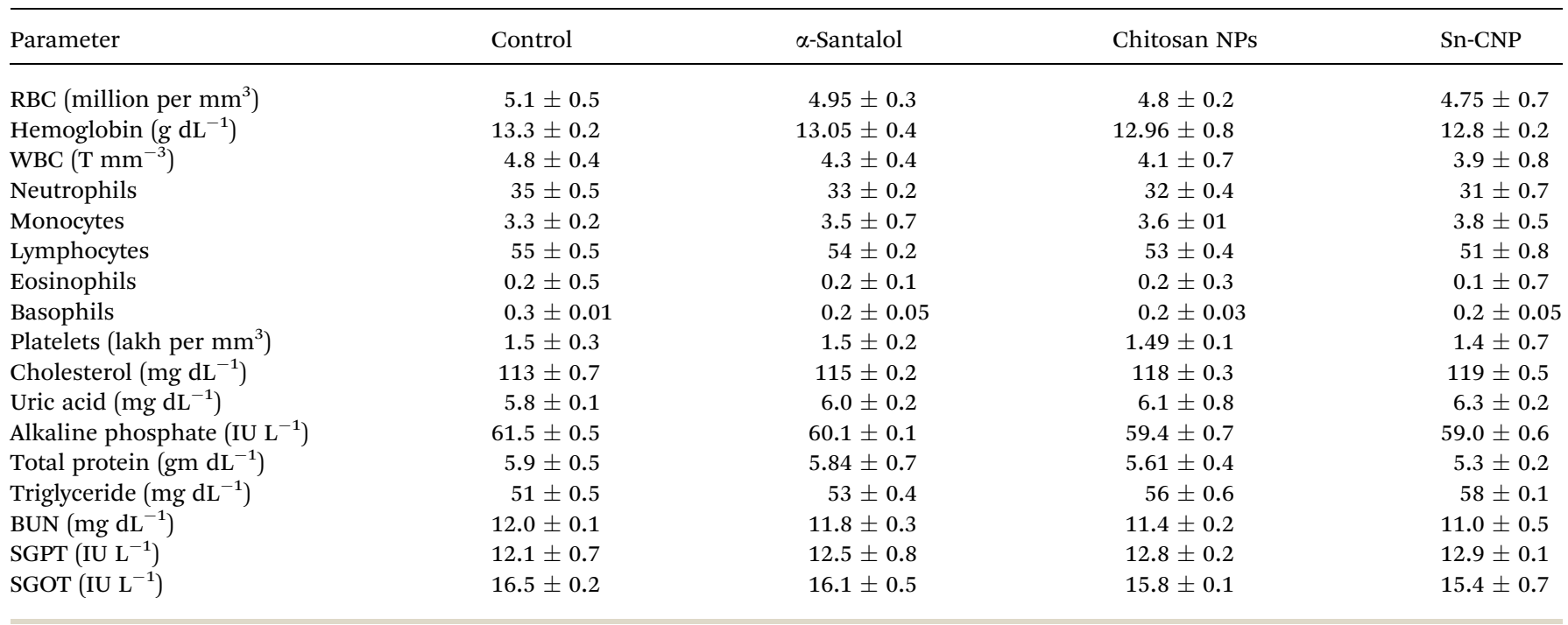

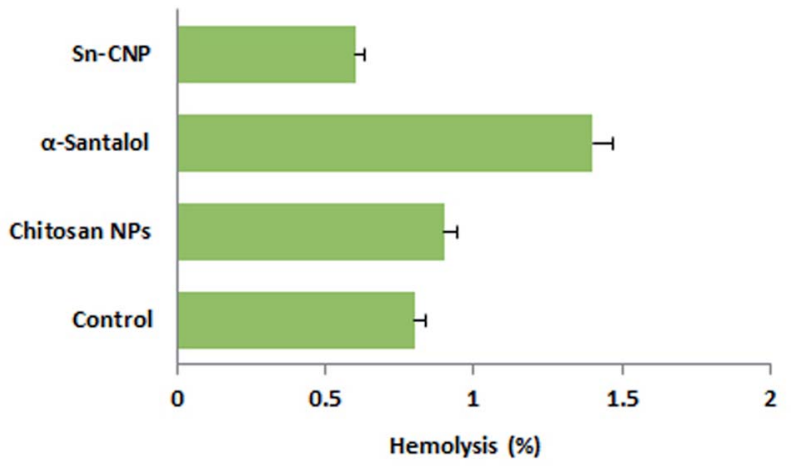

Fig. 17 Hemolytic activity of the synthesized Sn-CNPs.

santalol and the chitosan NPs. It is well known that the extracellular $\mathrm{pH}$ of tumors is slightly more acidic than that of blood and normal tissues. Thus, the electrostatic interaction that exists in neutral surroundings will disappear in an acidic environment. Thus, pH 5.5 facilitates the efficient release of loaded $\alpha$-santalol, which is significant as it implies that there will be better drug delivery in the tumor microenvironment.

\subsection{In vitro analysis}

3.2.1. Effect of Sn-CNP on cell viability. The cytotoxic activity of the functionalized chitosan NPs was analyzed. The compound showed a reduced percentage viability of the cells with increasing concentration of the nanomaterials. The in vitro cytotoxic effect of the NPs against MDA-MB-231 cells is depicted in Fig. 7A. Table 2 presents the analyzed inhibitory concentration $\left(\mathrm{IC}_{50}\right)$ of the synthesized nanomaterials and it was found to be $13 \mu \mathrm{g} \mathrm{mL}^{-1}$ for $\alpha$-santalol, $5 \mu \mathrm{g} \mathrm{mL}^{-1}$ for Sn-CNPs and insignificant toxicity was found up to $100 \mu \mathrm{g} \mathrm{mL} \mathrm{m}^{-1}$ for chitosan NPs. The $\mathrm{IC}_{50}$ concentration of the Sn-CNPs was found to be significantly lower when compared with that of the other treatment groups, whereas the synthesized nanomaterials were found to exhibit biocompatibility with normal breast cells
(Fig. 7B). Santha et al. reported the anti-cancer efficacy of $\alpha$ santalol against MDA-MB-231 cells to be higher with increasing concentration and with an elapsed period of treatment. Against normal breast cancer cells, the compound exhibited significant cell death only at high concentrations. ${ }^{39}$ Also, another study by Bommerady et al. reported that $\alpha$-santalol showed low toxicity against normal prostate epithelial cells (PrEC), while it had a significant toxic effect against prostate cancer cells (PC-3). ${ }^{41}$

3.2.2. Effect of Sn-CNPs on cell morphology. The alterations which are made in the MM2 cells on account of treating it with the synthesized NPs at $\mathrm{IC}_{(50)}$ were examined and interpreted in Fig. 8A. It can be observed from the figure that the SnCNPs treated cells had shown significant morphological changes including membrane blebbing and cell shrinkage. Floating cells are also observed in a dose-dependent manner. In normal breast tissue, there was no significant toxic effect up to $100 \mu \mathrm{g} \mathrm{mL} \mathrm{m}^{-1}$ (Fig. 8B). It is a well-recognised phenomenon that the cytological examinations interpret the antiproliferative effect routed with the above mentioned changes through the synthesized nanoparticle. Thus, the treated cells showed distinguished morphology including fragmented apoptotic bodies, margination, and shrunken nuclei when compared to untreated cells, which are signs of apoptosis. ${ }^{52}$

\subsection{Effect of Sn-CNPs on apoptosis and nuclear fragmentation}

Apoptosis, a vital cellular pathway, plays an important role in maintaining the equilibrium of our body..$^{53}$ In order to assess the apoptogenic activity of the synthesized NPs, fluorescence microscopic analysis was done using $\mathrm{AO} / \mathrm{EtBr}$ staining. The fluorescence microscopic analysis of the chitosan NPs, $\alpha$-santalol and Sn-CNP treated and untreated cancer cells are depicted in Fig. 9. Fig. 9a shows that the untreated MDA-MB-231 cells (control) did not have any significant effect when compared to the treated cells. Subsequently, Fig. 9b-d indicates the conversion of green-colored cells to orange/red colored cells, which is 
due to the initiation of apoptosis and the nuclear condensation effect occurred due to the action of the synthesized NPs.

In order to further distinguish the apoptotic nuclei from the healthy ones, 4',6-diamidino-2-phenylindole (DAPI), a nuclear stain, was used and the results of the MDA-MB-231 cells (treated and untreated) are portrayed in Fig. 10. As seen in Fig. 10a, the untreated cells show weak fluorescence as they have intact round nuclei. In contrast, the functionalized NP treated cells (Fig. 10d) emit high fluorescence when viewed under a microscope, which is due to the nuclear fragmentation of condensed apoptotic nuclei. Similarly, Bommareddy et al. highlighted the effect of $\alpha$-santalol on prostate cancer by apoptotic induction of the compound in PC-3 and LNCaP cells. ${ }^{41}$

\subsection{Effect of Sn-CNP on apoptosis by flow cytometry}

In order to evaluate the mechanism by which the synthesized NPs exerted apoptosis, the cells were treated with Annexin V/ FITC. The histogram (Fig. 11) of the cell cycle analysis describes the distribution of necrotic cells in the upper left quadrant (I); late apoptotic cells in the upper right quadrant (II); live cells in the lower left quadrant (III); and early apoptotic cells in the lower right quadrant (IV). From Fig. 11, it is found that the functionalized NPs increase the level of apoptotic cells in a significant way, evidencing their efficacy against TNBC. Kaur et al. noted strong apoptotic activity against skin cancer cells (A431) induced by $\alpha$-santalol, which relates to the significance of the present study. ${ }^{54}$ As chitosan is a biocompatible polymer, it is not involved in the apoptotic cell death of the cancer cell, ${ }^{55}$ while the Sn-CNPs induced significant apoptotic death upon treatment.

\subsection{Effect of Sn-CNPs on apoptotic protein expression}

The signaling pathway of apoptosis involves a complex number of molecules. ${ }^{56}$ To disclose the apoptotic pathway induced by the Sn-CNPs in MDA-MB-231 cells, western blot analysis was done to quantify the expression of a wide range of apoptotic genes (Fig. 12). Remarkably, it was identified that there is an upregulation in apoptotic proteins including BAX, BAD, caspase-3, and caspase-9, while on the other hand there was a noticeable down-regulation in the anti-apoptotic protein BCL2 and PLK-1. Notably, our results were correlated with the fact that depletion or down-regulation of PLK-1 will induce mitotic failure, DNA damage responses and finally apoptosis of the cells. $^{57}$

\subsection{Effect of Sn-CNPs on apoptotic gene expression}

To investigate the targetability of the Sn-CNPs on PLK-1 gene expression in MM2 tumor cells, the RNA was quarantined from the treated cells and was subjected to RT-PCR. Our study (from Fig. 13) highlighted that the Sn-CNPs lower or down regulate the expression of PLK-1 in a significant way. Likewise, a previous study emphasized the activity of ASO-loaded HSA NPs on PLK-1 expression in treated BT-474 cells, which also demonstrated significant down-regulation..$^{58}$

\subsection{Evaluation of in vivo analysis of $\alpha$-santalol loaded chitosan nanoparticle}

The efficacy of Sn-CNPs in in vivo therapeutics plays a pivotal role in determining their medical prospectives. The upshot of the synthesized NPs on the tumor volume and the body weight of the animals were examined and are shown in Fig. 14 and 15, respectively. There is a significant inhibition in the proliferation of MDA-MB-231 cells in the Sn-CNP treated mice, as denoted by the decrease in tumor volume (Fig. 14A) and tumor weight (Fig. 14B) when compared with the mice treated with saline. The Dox treated mice showed a significant reduction in tumor volume when compared with other treatment groups. Similarly, the mice administered with Sn-CNPs showed a significant reduction in their body weight when compared with the control group (Fig. 15). The histopathological analysis of H\&E stained organs (brain, heart, kidney, lung, and liver) of mice treated with the Sn-CNPs showed no adverse effects at the desired concentration and are depicted in Fig. 16. The results of previous investigations highlighted that $\alpha$-santalol is a potent inhibitor of skin papilloma proliferation in both CD-1 and SENCAR strains of mice. ${ }^{59}$

The hematological and biochemical parameters of animals from various treatment groups were analyzed and tabulated (Table 3). There is a decrease in hemoglobin, RBCs, and platelet counts when compared with that of the control group, while there was a differential count of WBC's. The monocyte count was increased whereas the neutrophil, lymphocyte, eosinophil, and basophil count was reduced. The biochemical parameters including cholesterol, uric acid, triglyceride, and SGPT levels increased whereas the alkaline phosphatase, total protein level, BUN, and SGOT levels decreased.

The hemocompatibility of the synthesized NPs with erythrocytes plays a pivotal role in the application of NPs in the biological system. ${ }^{60}$ The RBCs were exposed to synthesized nanomaterials, which were prepared for nearly $3 \mathrm{~h}$. The hemolytic activity of the control, chitosan NPs, $\alpha$-santalol, and Sn-CNPs were determined by measuring the release of the erythrocytes and are shown in Fig. 17. Based on a previous report, which highlighted the use of biomaterials until $5 \%$ hemolysis is observed, ${ }^{61}$ the SN-CNPs can be used as a potent biocompatible nanotarget to treat TNBC.

\section{Conclusion}

In this study, our findings nurture the opportunity of using phytocompound ( $\alpha$-santalol) as a targeting mediator against triple negative breast cancer both in vitro and in vivo. It can be used as an effective drug delivery system and also provokes a cytotoxic effect in selective triple negative breast cancer cells. Moreover, the Sn-CNPs were less toxic to normal breast cells and thus, assumed to be biocompatible in living systems at the given concentration. Additionally, it has the capability to initiate apoptosis inducing activities in the selected TNBC cells and at the same time, it can down-regulate the main cancerpromoting protein (PLK), leading to cell growth inhibitory activity. Taken as a whole, our synthesized nanomaterials 
effectively inhibit triple negative breast cancer cell growth in vitro and in vivo. Thus, our study evokes the idea of treating TNBC with biocompatible $\alpha$-santalol loaded chitosan NPs as an efficient drug delivery system for breast cancer therapy.

\section{Conflicts of interest}

There are no conflicts to declare.

\section{Acknowledgements}

The Health and Biomedical Special Project of Hebei Province Key R \& D Project (2018) (18277732D) is acknowledged for funding.

\section{References}

1 K. K. Thakur, D. Bordoloi and A. B. Kunnumakkara, Clin. Breast Cancer, 2018, 18, e393-e399.

2 M. Hubalek, T. Czech and H. Müller, Breast Care, 2017, 12, 814.

3 C. M. Perou, T. Sørlie, M. B. Eisen, M. van de Rijn, S. S. Jeffrey, C. A. Rees, J. R. Pollack, D. T. Ross, H. Johnsen, L. A. Akslen, Ø. Fluge, A. Pergamenschikov, C. Williams, S. X. Zhu, P. E. Lønning, A.-L. Børresen-Dale, P. O. Brown and D. Botstein, Nature, 2000, 406, 747-752.

4 S. Jiao, W. Xia, H. Yamaguchi, Y. Wei, M.-K. Chen, J.-M. Hsu, J. L. Hsu, W.-H. Yu, Y. Du, H.-H. Lee, C.-W. Li, C.-K. Chou, S.-O. Lim, S.-S. Chang, J. Litton, B. Arun, G. N. Hortobagyi and M.-C. Hung, Clin. Cancer Res., 2017, 23(14), 3711-3720.

5 D. Wen, J. Wu, L. Wang and Z. Fu, Cell Rep., 2017, 21, 21472159.

6 M. Raab, M. Sanhaji, Y. Matthess, A. Hörlin, I. Lorenz, C. Dötsch, N. Habbe, O. Waidmann, E. Kurunci-csacsko, R. Firestein, S. Becker and K. Strebhardt, Sci Rep., 2019, 9(1), 1-17.

7 S. Y. Lee, C. Jang and K. A. Lee, Dev. Reprod., 2014, 1, 65-71. 8 A. K. Roshak, E. A. Capper, C. Imburgia, J. Fornwald, G. Scott and L. A. Marshall, Cell. Signalling, 2000, 12, 405-411.

9 I. Sumara, E. Vorlaufer, P. T. Stukenberg, O. Kelm, N. Redemann, E. A. Nigg and J. M. Peters, Mol. Cell, 2002, 9, 515-525.

10 S. Kotani, S. Tugendreich, M. Fujii, P. M. Jorgensen, N. Watanabe, C. Hoog, P. Hieter and K. Todokoro, Mol. Cell, 1998, 1, 371-380.

11 T. Zhou, J. P. Aumais, X. Liu, L. Y. Yu-Lee and R. L. Erikson, Dev. Cell, 2003, 5, 127-138.

12 B. D. Cholewa, X. Liu and N. Ahmad, Cancer Res., 2013, 73, 6848-6855.

13 Z. Fu, L. Malureanu, J. Huang, W. Wang, H. Li, J. M. van Deursen, D. J. Tindall and J. Chen, Nat. Cell Biol., 2008, 10, 1076-1082.

14 X. S. Liu, B. Song and X. Liu, EMBO Rep., 2010, (8), 626-632.

$15 \mathrm{~J}$. Wu, A. I. Ivanov, P. B. Fisher and Z. Fu, eLife, 2016, 5, e10734.

16 M. A. T. M. van Vugt, A. Brás and R. H. Medema, Mol. Cell, 2004, 15, 799-811.
17 Z. Liu, Q. Sun and X. Wang, Transl. Oncol., 2017, 1, 22-32.

18 L. Cheng, C. Wang and J. Jing, Curr. Pharm. Des., 2015, 21, 1347-1350.

19 Z. Liu, Q. Sun and X. Wang, Transl. Oncol., 2017, 10, 22-32. 20 S. B. Hartono, N. Truong Phuoc, M. Yu, Z. Jia, M. J. Monteiro, S. Qiao and C. Yu, J. Mater. Chem. B, 2014, 2, 718-726.

21 W. Gu, Z. Jia, N. P. Truong, I. Prasadam, Y. Xiao and M. J. Monteiro, Biomacromolecules, 2013, 14, 3386-3389.

22 S. Parveen and S. K. Sahoo, J. Drug Targeting, 2008, 16(2), 108-123.

23 M. Sharma, R. Sharma, D. K. Jain and A. Saraf, Int. J. Biol. Macromol., 2019, 135, 246-260.

24 S. Natesan, C. Ponnusamy, A. Sugumaran, S. Chelladurai, S. Shanmugam Palaniappan and R. Palanichamy, Int. J. Biol. Macromol., 2017, 104, 1853-1859.

25 J. Zhang, W. Xia, P. Liu, Q. Cheng, T. Tahirou, W. Gu and B. Li, Mar. Drugs, 2010, 8, 1962-1987.

26 B. Ates, A. Ulu, S. Köytepe, S. A. Ali Noma, V. S. Kolat and T. Izgi, RSC Adv., 2018, 8, 36063-36075.

27 Z. B. Wang, P. Shan, S. Z. Li, Y. Zhou, X. Deng, J. L. Li, Y. Zhang, J. S. Gao and J. Xu, RSC Adv., 2016, 6, 96785-96797.

28 M. Omidi, A. Yadegari and L. Tayebi, RSC Adv., 2017, 7, 10638-10649.

29 P. Pandey, K. Dua and H. Dureja, Int. J. Biol. Macromol., 2019, 139, 1304-1316.

30 G. A. Morris, J. Castile, A. Smith, G. G. Adams and S. E. Harding, Carbohydr. Polym., 2011, 84, 1430-1434.

31 W. Fan, W. Yan, Z. Xu and H. Ni, Colloids Surf., B, 2012, 90, 21-27.

32 J. Varshosaz, E. Moazen and M. Fathi, J. Dispersion Sci. Technol., 2012, 33, 1480-1491.

33 Q. Gan and T. Wang, Colloids Surf., B, 2007, 59, 24-34.

34 T. Takigawa and Y. Endo, J. Occup. Health, 2006, 48, 75-87.

35 G. A. Burdock and I. G. Carabin, Food Chem. Toxicol., 2008, 46, 421-432.

36 A. Mohankumar, G. Shanmugam and D. Kalaiselvi, RSC Adv., 2018, 8(59), 33753-33774.

37 B. B. Misra and S. Dey, Phytomedicine, 2013, 20, 409-416.

38 M. Paulpandi, S. Kannan, R. Thangam, K. Kaveri, P. Gunasekaran and C. Rejeeth, Phytomedicine, 2012, 19, 231-235.

39 S. Santha, A. Bommareddy, B. Rule, R. Guillermo, R. S. Kaushik, A. Young and C. Dwivedi, PLoS One, 2013, 8, e56982.

40 X. Zhang, W. Chen, R. Guillermo, G. Chandrasekher, R. S. Kaushik, A. Young, H. Fahmy and C. Dwivedi, BMC Res. Notes, 2010, 3, 220.

41 A. Bommareddy, B. Rule, A. L. VanWert, S. Santha and C. Dwivedi, Phytomedicine, 2012, 19, 804-811.

42 S. Saraswati, S. Kumar and A. A. Alhaider, Mol. Cancer, 2013, $12,147$.

43 A. A. Elzatahry and M. S. M. Eldin, Polym. Adv. Technol., 2008, 19, 1787-1791.

44 K. Kavithaa, M. Paulpandi, P. R. Padma and S. Sumathi, RSC Adv., 2016, 6, 64531-64543.

45 T. Ponraj, M. Paulpandi, R. Vivek, K. Vimala and S. Kannan, Int. J. Biol. Macromol., 2017, 95, 1235-1245. 
46 B. Krishnaveni and P. Priya, Int. J. Chem. Stud., 2014, 1(6), 10-20.

47 W. Zhang, J. Zhang, Q. Jiang and W. Xia, Carbohydr. Polym., 2012, 87, 309-313.

48 S. Vaezifar, S. Razavi, M. A. Golozar, S. Karbasi, M. Morshed and M. Kamali, J. Cluster Sci., 2013, 24, 891-903.

49 M. I. Guerra-Rosas, J. Morales-Castro, L. A. Ochoa-Martínez, L. Salvia-Trujillo and O. Martín-Belloso, Food Hydrocolloids, 2016, 52, 438-446.

50 E. Blanco, H. Shen and M. Ferrari, Nat. Biotechnol., 2015, 33(9), 941-951.

51 D. E. Owens and N. A. Peppas, Int. J. Pharm., 2006, 307(1), 93102.

52 S. Elmore, Toxicol. Pathol., 2007, 35, 495-516.

53 J. F. R. Kerr, A. H. Wyllie and A. R. Currie, Br. J. Cancer, 1972, 26, 239-257.

54 M. Kaur, C. Agarwal, R. P. Singh, X. Guan, C. Dwivedi and R. Agarwal, Carcinogenesis, 2005, 26, 369-380.
55 M. Thanou, J. Verhoef and H. Junginger, Adv. Drug Delivery Rev., 2001, 52, 117-126.

56 P. Chanphai and H. A. Tajmir-Riahi, Int. J. Biol. Macromol., 2017, 98, 535-541.

57 L. Xiaoqi and L. K. Raymond, Proc. Natl. Acad. Sci. U. S. A., 2003, 100(10), 5789-5794.

58 B. Spänkuch, I. Steinhauser, H. Wartlick, E. KurunciCsacsko, K. I. Strebhardt and K. Langer, Neoplasia, 2008, 10, 223-234.

59 C. Dwivedi, X. Guan, W. L. Harmsen, A. L. Voss, D. E. GoetzParten, E. M. Koopman, K. M. Johnson, H. B. Valluri and D. P. Matthees, Chemopreventive Effects of-Santalol on Skin Tumor Development in CD-1 and SENCAR Mice 1, 2003. 60 R. K. Kainthan, M. Gnanamani, M. Ganguli, T. Ghosh, D. E. Brooks, S. Maiti and J. N. Kizhakkedathu, Biomaterials, 2006, 27, 5377-5390.

61 J. P. Singhal and A. R. Ray, Biomaterials, 2002, 23, 1139-1145. 